\title{
Left Behind to Farm? Women's Labor Re-Allocation in Rural China
}

\author{
Ren $\mathrm{Mu}^{\mathrm{a}}{ }^{* *} \quad$ Dominique van de Walle ${ }^{\mathrm{b}}$
}

${ }^{a}$ The Bush School of Government and Public Service, Texas A\&M University, 4220

TAMU, College Station, TX, 77843, USA. Email: rmu@tamu.edu

${ }^{b}$ The World Bank, 1818 H Street, NW, Washington, DC, 2006, USA. Email:

dvandewalle@worldbank.org

\begin{abstract}
The transformation of work during China's rapid economic development is associated with a substantial but little noticed re-allocation of traditional farm labor among women, with some doing much less and some much more. We study how the work and time allocation of non-migrant women are affected by the outmigration of others in their household. We find that the women left behind are doing more farm work than would have otherwise been the case. We also find evidence that this is a persistent effect, and not just temporary re-allocation. In stark contrast, no such impacts are found for left-behind men.
\end{abstract}

\footnotetext{
* Financial support from the World Bank's Gender Action Plan and the faculty research grant from the Scowcroft Institute at the the Bush School of Government and Public Service, Texas A\&M University is gratefully acknowledged. We are grateful to Feng Huang and Xiaoyang Li for great research assistance and to Alan de Brauw, Deborah DeGraff, Gayatri Koolwal, Sylvie Lambert, Andrew Morrison, Martin Ravallion, John Strauss, Adam Wagstaff, seminar participants at the Chinese Economist Society 2009 conference and the Population Association of American 2010 conference, the journal's editor and two referees for very useful comments. The findings, interpretations, and conclusions expressed in this paper do not necessarily represent the views of the World Bank, its Executive Directors, or the countries they represent.

** Corresponding author. Tel: 1-979-458-8024; Fax: 1-979- 845-4155.
} 


\section{Introduction}

As the economics profession has come to seriously question income-pooling models of the household based on empirical evidence, the possibility arises that many aspects of overall economic development may come with distributional effects within households, with likely gender dimensions. ${ }^{1}$ A case in point is migration during the process of structural transformation of a largely rural-based agricultural economy to a more urban-based economy. Typically, only some members of the rural household migrate, leaving others behind. While the literature on migration has traditionally had a lot to say about the impacts on the total income of rural households - notably through remittances - the rejection of an income pooling model and the importance of nonincome factors to welfare suggest a need to examine the welfare impacts on those left behind in rural areas. This is in keeping with the recent new literature on migration emphasizing intra-household behavioral responses (reviewed later).

In this paper, we focus on non-migrant women and how their work, time allocation and health are affected by living in a migrant household. The equity arguments are often related to women's empowerment and neglect other aspects of welfare, such as the type of work and time for leisure. Left-behind women may be more empowered but at the expense of being over-worked, with direct implications for their well-being, including their leisure and health. Household income may increase with migrants' remittances, but women's well-being may not.

The setting for our study is rural China. In trying to evaluate women's welfare changes resulting from current migration patterns in rural China, we first focus on the

\footnotetext{
${ }^{1}$ Bourguignon etc (1993), Browning and Chiappori (1998) provide theories of non-unitary household models. Examples of empirical rejections of the income pooling assumption in developing countries are Thomas (1994) and Duflo (2003).
} 
effects on women's total working hours and (hence) their leisure, which is assumed to be an important determinant of welfare. We also explore impacts on labor time allocation across productive activities including on and off the farm, both in terms of participation and hours. As China transitions out of agriculture, a key question is whether some groups are being held back in farm work, which could limit their social and economic mobility. Health is another important dimension of welfare that may be impacted being left behind as well as possibly bearing a larger work burden may increase women's stress and fatigue, and lead to potential health problems. Finally, we look at whether there is any evidence of female empowerment through increased managerial responsibilities for household productive activities. This too could affect well-being and possibly balance out other negative effects of being left-behind.

Understanding the welfare of left-behind rural women has important implications for aggregate growth and for policy. Improvements in the public provision of child and elderly care or support may help alleviate the burden of household production on the women staying behind. Extension services are particularly important as many nonmigrant women have lower education and knowledge about farming. There may also be a role for public policy and anti-poverty reduction strategies to help the left-behind women through better services in health care, credit, non-farm employment and safety nets. However, since the left-behind phenomenon changes the population structure of rural areas, and is caused partly by distortions and policy failures in the migration destination market (notably through China's household registration system discussed below), correcting these distortions and failures may be a more effective and long-lasting solution. 
We find evidence of significant re-allocation across labor force activities, with substantially more hours worked in agriculture by left-behind women and fewer worked in wage or family business activities. These effects differ across age cohorts, some of whom also suffer a consequent reduction in leisure. In general, these time allocation effects are associated with the migration of offspring and husbands and are not reversed when migrants return, with seemingly permanent consequences. We find no sign of effects on health or empowerment.

An obvious question is whether these patterns are specific to women or shared also by non-migrant men in rural China. The same analysis for men reveals no impacts on labor force activities, time allocation or health for those left-behind.

The next section briefly reviews the relevant literature and identifies the contributions of this paper. Section 3 then describes the data. This is followed in Section 4 by some descriptive tables and figures documenting recent trends in rural labor force participation in various activities and in rural to urban migration by gender. The covariates of female migration for the period 1997 through 2006 are also examined. Section 5 then first turns to the impacts on non-migrant women of living in migrant households and ends with a brief examination of the same issues for non-migrant men. Section 6 concludes.

\section{Literature review}

The sweeping economic changes experienced by China in recent decades have transformed the division of labor by both occupation and gender. Since the introduction of agricultural and other reforms in the late 1970s, labor markets and the nature of labor force participation have changed significantly in rural areas. With the gradual relaxation 
of restrictions on rural to urban migration the country experienced one of the largest flows of labor out of agriculture in world history. Rapidly increasing migration throughout the economic reform period has been associated with economic growth (for example, see Liang and Ma, 2004; Fan, 2008).

For reasons elaborated on below, much of this migration remains temporary with rural households retaining members and agricultural land in their ancestral villages. The existing division of labor by gender, informal rules and gender norms in intra-household decision-making suggest that the propensity for migration in China will differ by gender (Murphy 2004). There was a rapid increase in the migration of men of all ages to jobs in urban areas (Zhao 2002). Some women followed suit, but their overall participation in migrant labor markets has lagged behind men's (Fan 2003, de Brauw et al. 2008). In the last decade or so, more women have joined in the rural to urban migration. However, as confirmed by our data, this is true particularly for young, single women (Du, et al. 2005, de Brauw et al 2008). For most rural women, marriage is synonymous with the termination of migrant work and return to the village (Fan 2004). Thus, older, married women continue to stay behind in rural areas.

Although reasons vary, women are found to be less likely to migrate for work than men in many developing countries (see for example, Amuedo-Dorantes and Pozo 2006; Mendola and Carletto 2009; Lokshin and Glinskaya 2008; and Rodriguez and Tionson 2001). In China, lagging female migration is thought to be due in part to women's occupational options as migrants tending to be inferior to men's (Fan 2003, Liang and Chen 2004). In addition, the gender trends reflect various constraints on opportunities that stem from market and governmental failures that are more binding for women. For example, China's Hukou, or household registration system, and rural land 
tenure insecurity have helped keep migration an impermanent event (de la Rupelle et al. 2009). Severe obstacles to switching one's registration from rural to urban areas prevent entire families from moving to cities since access to urban health and education services and social safety nets is linked to registration (World Bank, 2009). Thus it is not surprising given prevailing gender norms, that women are more likely than men to stay behind in rural areas with their families. ${ }^{2}$ Other constraints tied up with insecure land tenure - whereby agricultural land holdings are subject to administrative re-allocation that can be triggered by absence or leaving the land temporarily uncultivated - may also be playing an important role. ${ }^{3}$ Such constraints, and the induced migration patterns, could well produce a distorted gender division of labor - with women taking responsibility for looking after children, elderly parents and the farm - and excessively gender-differentiated labor markets, at a cost to both equity and efficiency.

Much of the migration literature for China and elsewhere has focused on the income effects of migration on those left behind. Migrants typically send back remittances. These are expected to have an income effect on the recipient households and may lead to a decline in left-behind women's labor supply. ${ }^{4}$ A counter-balancing effect may be felt through the costs of migration and the need to compensate for the loss of household labor and the associated foregone income. Missing land rental markets may prevent leasing out land and also dampen the income effect on women's welfare.

\footnotetext{
${ }^{2}$ The policy regime underlying these constraints is changing over time. Registration is becoming easier to obtain for rural migrants. A potentially important change in 1998 is that children born from mothers with rural registrations living in urban areas can be given urban registration. Individuals with rural hukou status can now purchase non-agricultural hukou status from urban governments, yet in many cases the system continues to work against more permanent migration flows (Fan, 2008).

3 A law introduced in 2002, the Rural Land Contract Law, guarantees farmers' land tenure security for at least 30 years during which no land reallocation is occur. However implementation is decentralized and varies across villages (Deininger and Jin, forthcoming)

${ }^{4}$ Research has also shown that migrant remittances can help households overcome credit constraints to invest in productive activities (e.g. Woodruff and Zenteno, 2007) or in the human capital of the next generation (e.g. Beine et al., 2008; Yang, 2008).
} 
Supervision and other transaction costs limit the scope for substituting hired labor. Leftbehind women are often solely responsible for child rearing which is more compatible with farm and household production than off-farm work (for this argument in the context of rural China, see Short et al. 2002). It has also been argued that some village collective authorities link security of land use rights to maintaining high agricultural production (Lohmar 1999). Thus out-migration of household members may well increase nonmigrant women's time in household and farm production despite the income effect of remittances.

Thus, how women's time allocation, leisure and labor force participation is affected by the out-migration of household members is an empirical issue. Studies for Albania (Mendola and Carletto 2009), the Philippines (Rodriguez and Tionson 2001), Mexico (Amuedo-Dorantes and Pozo 2006) and Nepal (Lokshin and Glinskaya 2008) have found the net effect to be a decline in labor force participation as well as in hours of paid work by female members of sending households. This issue has not been analyzed in the rural China context to our knowledge. ${ }^{5}$

It is generally believed that China's recent labor market changes have increased mean national income and mean household welfare. For example, de Brauw and Giles (2008) carefully document the positive impacts of migrants on household living standards in rural China. However, there is an ongoing debate about how these trends have affected women's welfare, both absolutely and relative to men. Some contributions focus on the new economic opportunities that rural to urban migration provides for women (Zhang et al. 2004), while others emphasize the multiple disadvantages faced by female

\footnotetext{
${ }^{5}$ Chen touches upon them in her analysis of bargaining within the household (2006a, 2006b). Using a sample of households with children aged 6 to 16 and co-resident parents she is interested in testing whether household resource allocation is cooperative. She finds that wives work less and consume more leisure when husbands migrate (2006b).
} 
migrants who are typically young, single and uneducated: segregated jobs, lower wages and discrimination (Fan 2003).

But as already pointed out and confirmed in Section 4, female migration lags behind that of men. Of more relevance to our concerns in this paper is the literature concerning impacts on the women who are left behind while their husbands or children migrate. Here too there is disagreement. Some argue that left behind women's welfare has risen as a result of increased autonomy and new decision making powers as household heads (Davin 1999). Improvements in farm efficiency are seen as enhancing the welfare of those who now manage and work the farms (Zhang et al. 2004, de Brauw et al. 2008). In addition, greater access to local off-farm work and to higher wages is claimed to have raised women's welfare.

Against that, the increased division of labor, with women typically holding down the low status, low value farm and household production work in rural areas is posited to have reinforced gender segregation and low status (Fan 2003). There has also been much debate about claims of a feminization of agriculture. However, careful examination of the evidence has conclusively shown these fears to be unfounded at least through the year 2000 (de Brauw et al. 2008). The evidence points to a large reduction in the hours worked in agriculture by both men and women since the reforms began as well as significant increases in off-farm work. On average, a smaller share of rural Chinese men and women now work on the farm (de Brauw et al. 2008).

Our contributions to the debates in the literature are two-fold. Our primary contribution to this literature is to analyze the impacts of migration on left behind women but extending the usual examination of aggregate effects of migration on labor force participation to differentiate those effects by age cohort, and also by whether the 
migration is of husbands, children, or other household members and finally by whether the effects of return migration are symmetric with those of out-migration. Although men are more likely to migrate than women, some are also left-behind. We broaden the analysis to examine whether men are affected by the migration of household members in similar ways to women.

In the process we also extend the documentation of recent trends in allocation to labor force activities, including work-related migration, by gender and age-cohort over time up through 2006. Most recently published analyses only take the trends up through 2000 (de Brauw et al., 2008). Some of the more recent trends are suggestive of a developing gender gap in farm work for middle aged women. We identify signs of changing patterns including potential increases in the participation of women in agricultural work.

\section{Data}

The main data used for the analysis are from the China Health and Nutrition Survey (CHNS), conducted by the University of North Carolina at Chapel Hill. ${ }^{6}$ This is a longitudinal survey that interviewed the same households in 1989, 1991, 1993, 1997, 2000, 2004, and 2006 in nine provinces: Guangxi, Guizhou, Henan, Hubei, Hunan, Jiangsu, Shandong, Liaoning and Heilongjiang. These provinces substantially differ geographically and with respect to their level of economic development. Attrition at the household level is less than $5 \%$ between waves, and some rotation of households began

\footnotetext{
${ }^{6}$ See http://www.cpc.unc.edu/projects/china for details.
} 
after $1993{ }^{7}$ The data for rural households are partly from the rural villages on the outskirts of county towns and partly from much more rural villages. We use the complete rural CHNS sample of about 3,800 households covering approximately 16,000 individuals.

The sample for each province followed a multistage, random cluster process whereby counties were stratified by income and a weighted sampling scheme was used to randomly select four in each province. Rural villages and rural suburban neighborhoods were selected randomly. The sample is made up of 36 suburban neighborhoods and 108 villages.

The CHNS collects detailed information on household demographics, education, health and nutrition, occupations and labor force participation, housing and asset ownership, time use, and incomes. One major advantage of the CHNS is that it contains detailed information on individual hours spent on various activities. For example, it records how many hours per day, days per week, and months per year each individual worked in the garden (vegetable plots near the house), on crop production, livestock, and fisheries; it asks about hours worked in wage labor, handicraft and small commercial household businesses. These questions about labor time allocation all refer to "the past year." We will however, refer to individuals' activities by the year of the survey round. ${ }^{8}$ In terms of domestic activities, the CHNS collects time allocation during the preceding week to various "household chores" in which are included buying and preparing food,

\footnotetext{
7 Accumulated individual attrition across the survey rounds used in this paper (1997 - 2006) is $46.3 \%$. Attrition for the first three waves $(1997,2000$ and 2004) is 36.5\% and 35.6\% for the last three (2000, 2004 and 2006).

${ }^{8}$ For example, if an individual reported in the 1997 survey round that she worked in a family business during the past year, we will refer to this as working in a family business in 1997.
} 
doing laundry, getting water, and cleaning house; hours spent in child and elderly care are also recorded separately.

The detailed information on time allocation across market, farm and household production allows us to map out women's behavioral responses to a household members' out-migration. However, time allocation information is not collected by means of complete time diaries so that measurement errors can arise in calculating leisure. A priori, there is no reason to believe that any existing measurement error is systematically related to a household member's migration status.

The CHNS was not originally conceived to study migration. The migration status of household members must be built up from the household roster. If an individual who was in a previous round is not in the current round of the survey, a question is asked regarding the location of this individual. However, it is only from the 1997 round on that the reason for being absent was also recorded. This allows us to distinguish "labor" migrants who left to seek work from individuals who left for motives such as marriage and schooling. For this reason, we use the 1997 and later rounds only. We will consider any individual who has left the home county for work reasons between two waves to be a migrant. A potential problem is that we may underestimate the migration rate because migrants in between surveys cannot be identified. However, there is no reason to believe that our identification of migrants captures long-term migrants better than short-term ones. Someone who is away for work reasons during a survey round is not necessarily one or the other. There may well be migrant members who have never been present during a survey round, and short term migrants who are present during one round but not the next. 
As its name implies, the CHNS provides multiple measures of health. We take advantage of some of these, and analyze how different facets of a woman's health - body mass index (BMI), self-reported health, and stress as measured by blood pressure - are affected by household member migration status. The available health measures are not ideal for our purposes and we will not be able to conclusively say whether and how health is affected. ${ }^{9}$ The surveys also include questions about which household member has the primary responsibility for the farm, and any fishing and gardening activities. We use this as one of our outcome variables as well to test whether women in migrant households are more likely to report being in charge.

It should be noted that some important variables are less well measured in the CHNS. For example, operated land amounts are often missing. We expect this to be a key covariate but can only control for whether households report having land or not.

\section{Labor allocation, women's migration and the left behind}

As a background to our analysis of the impacts on women of living in migrant households, we describe labor force participation rates and allocation across activities by gender and their evolution over time. We also examine women's migration and its determinants, and women's non-migration. A key result of the section is that more women than men are in fact being left behind.

\subsection{Gender differences in labor allocation}

Using the four survey rounds of the CHNS as a pooled cross-section we categorize respondents aged 16-70 into four sectors of activity at each date: "migrant"

\footnotetext{
9 The prevalence of high blood pressure has been rising in rural China particularly among women and is linked to lifestyle changes as well as mental stress associated with rapid social change (Dong et al. 2008).
} 
employment (for which migration is necessary), rural agricultural self-employment, rural off-farm self-employment (family business) and rural local wage employment. ${ }^{10}$ Table 1 also presents overall labor force participation rates for men and women in this age group as well as mean age and years of education for those involved in each activity for 1997, 2000, 2004 and 2006. Participation is defined as one if an individual reported being engaged in the activity in either their primary or secondary occupations and is expressed in percentages. $^{11}$

As can be seen in Table 1, the labor force participation rates of rural individuals aged 16 through 70 fell from 89 to $82 \%$ for men, and from 86 to $73 \%$ for women between 1997 and 2006. ${ }^{12}$ Work-related migration increased substantially for both men and women. The male migration rate tripled from 7.8 to $24.5 \%$. However, despite a similar threefold increase (5.6 to $14.9 \%$ ), the female migration rate remains much lower than men's. The unconditional gender gap in the migration rate increased over time from about $2 \%$ in 1997 to almost $10 \%$ nine years later.

The percent of men and women engaging in agricultural self-employment are similar on average. Both declined from around 76 to around $56 \%$ over the period. The percentages working locally for a wage declined somewhat between the late 1990s and mid 2000 s to $23 \%$ for men and $16 \%$ for women. There appears to be a slight increasing trend in the percent of women employed in family businesses - from 10\% in 1997 to about $12 \%$ in 2006.

\footnotetext{
10 Labor migration can be to other rural areas although the bulk of employment for which migration is necessary is urban.

${ }^{11}$ There is no minimum time requirement for being recorded as a participant and participation in on- and off-farm rural employment activities are not mutually exclusive. As a result, participation across the four activities does not add up to one hundred percent for each year.

12 These trends are confirmed in the census. Based on the $0.966 \%$ sample of the 2005 Chinese Census, the rural labor force participation rate in 2005 is 84.2\% for men (aged 16-70) and 71.3\% for women (aged 1670). According to the $1 \%$ sample of 2000 Chinese Census, the rate is $87.7 \%$ for men and $76.7 \%$ for women in 2000. We thank Meiyan Wang in IPLE-CASS for providing the information.
} 
Migrants are the youngest among the four labor categories, and female migrants are on average younger than male migrants. Those self-employed in agriculture are the oldest and least educated workers while those employed in local wage work have the highest levels of education. It is also clear that women have less education than men across all employment categories. The profile of workers across activities is consistent with that found in other studies based on different data sources (for example, Zhao 1999).

Averages across men and women as presented in Table 1 mask the fact that gender differences in labor allocation to activities vary substantially across age groups. These are also changing over time. As shown in Figure 1, the very youngest women have, at least since 1996, had a higher migration rate than the youngest men. But women in general are less likely to migrate than men, and the gender gap in migration widens significantly over time. ${ }^{13}$ This reflects the fact that although more women are migrating over time, more men are also doing so at an increasing rate. Women under 45 work in agriculture at about the same rate as men before 2006, echoing the findings of de Brauw et al. (2008). However, a gap emerges in the 2006 data with women in their 30 s more likely to be employed in agriculture than men in the same age groups (Figure $1 \mathrm{~b}) .^{14}$ Women at older ages continue to be less likely to work in agriculture. Women's participation in local non-farm work (whether wage or off-farm family businesses) has also lagged behind men but shows signs of catching up over time, especially at younger ages.

\footnotetext{
${ }^{13}$ These are non-parametric regressions of locally weighted smoothed scatter plots.

14 An OLS regression suggests that, conditional on province fixed effects, women in this group are $8 \%$ more likely than men to work in agriculture. This gender difference is statistically significant at the $5 \%$ level. The increase in the gender difference is also statistically significant at the $5 \%$ level compared to 1997 when women in the same age group are only $1.5 \%$ more likely to work in agriculture.
} 
We conclude from the above descriptive information that, with the exception of the very youngest, women are indeed lagging behind in leaving farms and seeking migrant employment opportunities. This gender gap is not closing but widening over time. Parallel to this trend, a higher percentage of women are staying behind in rural areas to run the farms and engage in local off-farm employment.

\subsection{The determinants of migration}

Although women in most age groups are being left behind, some still migrate. What factors affect whether a rural woman migrates for work? The panel and the repeated observations over time on rural individuals allow us to identify non-migrant women - here defined as women aged 7 to 52 in 1997 (16 to 61 in 2006) who report no migration experience during the CHNS panel survey period - and women in the same age group who do. Among the 2592 observations with non-missing values for key variables, $563(22 \%)$ ever migrated in the ensuing years. Using a probit model, we explore what initial 1997 individual, household and geographic/village characteristics are associated with a higher probability of subsequent migration. We carry out the same analysis for men. Since the specific probit values are not the main concern of the paper, we limit discussion to a brief summary of the results here. (The probit estimates for women and men converted to marginal impacts are given in Appendix Table 2.)

Age is a key correlate. Migration is highest for the youngest women and drops continuously with age. The relatively better educated are more likely to be migrants. However, the more educated the household head (typically their husband or father), the less likely the migration. Controlling for age, marital status is not a significant determinant. The only important household compositional factor appears to be the number of males aged between 7 and 60 which is positively associated with young 
women's migration. The value of household assets per capita has non-linear effect young women in worse-off as well as better-off households are less likely to migrate. ${ }^{15}$ This is consistent with the finding in Du et al. (2005) that at low income levels, the likelihood of migration increases with wealth; however, at moderate levels of income, migration declines with wealth. Among village characteristics, the migration network as measured by the percentage of inhabitants who were migrants in 1997, is positively related to young women's migration; better local labor market conditions as proxied by the percent of villagers working in small or large enterprises (more than 20 employees) in 1997 has a negative effect. Finally the presence of a senior middle school in the village reduces their migration. The results for men mirror those for women and reveal no evidence that migration decisions differ by gender.

Whether an individual migrates is clearly a household decision, which is unsurprisingly influenced by individual attributes but also by household and village characteristics. This suggests that the welfare of non-migrant women will be affected by other household members' migration.

\subsection{Non-migrant women in migrant households}

What proportion of non-migrant women live in households with migrant members during the period covered by the surveys? Using information from the household roster, supplemented with the matched parent-child identification data provided by the CHNS, we can link migration information of parents, husbands, and children with non-migrant women resident in the same households. Table 2 gives, by age cohort and survey year, the percent of women who were not themselves migrants at the time of each survey round but lived in households with migrant members. For the 16 to 20 age group, Table 2

\footnotetext{
${ }^{15}$ The value of assets aggregates the value of owned productive and consumption assets recorded in the CHNS. It does not include land assets.
} 
reports parents' and siblings' migration status, while it shows husbands' and children's migration for the older groups. ${ }^{16}$

In all age groups, an increasing percent of non-migrant women live in migrant households over time. About $11 \%$ of the youngest women did so in 1997 , while $37 \%$ did in 2006. Both the incidences of having parents and siblings who migrate for work increase substantially over the nine year period from 5 to $17 \%$ and 5 to $21 \%$, respectively.

Around $85 \%$ of non-migrant women in the 21 to 35 age group are married. Pooling the married and unmarried, we see that the share of women living in migrant households in this age cohort increases from 6 to $21 \%$. Conditional on being married, $13 \%$ live in a migrant household and $10 \%$ have a migrant husband in 2006 - a share that increased significantly from $3 \%$ in 1997 . Note that the sample size for this age group declines from 649 to 186 , which reflects the higher attrition of young women both through migration and marriage.

Women aged 36 to 50 , and 51 to 60 are far more likely to live in a migrant household than younger women. Although the migration rates for their husbands increase steadily from 3 to $12 \%$ and 1 to $7 \%$ over time, the migration of their children is the dominant phenomenon. It rises from around 15 to $40 \%$ for both groups. Although it continues to increase over time, spousal migration for non-migrant women in the 51-60 age group decreases significantly when compared to that for the younger cohorts. Having a migrant husband is far less common for women aged 61 and above (2.5\% in 2006) consistent with the fact that men's migration declines with age - as is having migrant children (25\% in 2006). ${ }^{17}$

\footnotetext{
${ }^{16}$ We summarize this information with respect to men in Section 5.3.

${ }^{17}$ This reflects the negative age effect on the migration of children. In addition, it may reflect adult children coming back to take care of elderly parents. This explanation is consistent with the findings in Giles and
} 


\section{Impacts of living in households with migrants}

We examine how living in a migrant household affects women's labor force participation, time allocation and welfare. Controlling for other household and individual factors, how does life compare for non-migrant women who are left behind by household members versus those that are not? Do left behind women devote more time to working on the farm and on household chores including child and elderly care? The data allow us to explore these questions convincingly with respect to time allocation both in terms of participation in different activities and the number of hours spent in those activities. Ultimately, we would like to know how welfare is affected. But welfare is hard to measure and in common with most surveys and studies, we are unable to compute a broad individual level welfare measure. Instead, we can look at a number of aspects of welfare including leisure, a number of physical and psycho-social health measures that may be suggestive of heightened stress or undernourishment (BMI, self-reported health status, and high or low blood pressure diagnosis) and one measure of empowerment given by whether women hold primary management responsibilities for running the farm. Davin (1999) and Zhang et al. (2004) have argued that through becoming decisionmakers and managers of productive activities women who are left behind may be empowered and hence better off. Again, we are unable to judge whether such responsibilities enhance welfare, but we can examine whether such management responsibilities do increase for left-behind women.

$\mathrm{Mu}$ (2007) that adult children are less likely to migrate when elderly parents are in poor health. Note that since no information is available for children who don't live in the surveyed households, child migration rates from the CHNS could both over- or under-estimate children's actual migration rate. If living with parents facilitates out-migration, then migration rates based on resident children will over-estimate the actual rate. If co-residence instead reflects care for parents, then resident children's migration will be an under-estimate. 


\subsection{Empirical strategy}

To evaluate how a household member's migration affects the time use and other outcomes of the left-behind women, one might choose a regression across all nonmigrant women of outcome measure $Y_{i j t}$ for individual woman $i$ in household $j$ at time $t$ :

$$
Y_{i j t}=\alpha_{0}+\alpha_{1} M_{j t}+X_{i j t} \alpha_{2}+H_{j t} \alpha_{3}+D_{p \times t}+v_{i}+\varepsilon_{i j t}
$$

The time use outcome measures include women's total working hours, and their component parts: working hours on the farm, off-the farm in either wage labor or a family business, and on household chores. $Y_{i j t}$ can also be a binary variable equal to 1 if woman $i$ participates in the above activities and zero otherwise. ${ }^{18} M_{j t}$ is a binary variable equal to 1 if household $j$ has at least one member who is away for work reasons at time $t$ and so is 'a migrant household' in our terminology. $X_{i j t}$ and $H_{j t}$ are vectors of individual and household characteristics, respectively, that affect individual $i$ 's outcomes, for example through preferences or ability to work on or off the farm locally. The vector $X_{i j t}$ includes individual $i$ 's age, years of schooling and marital status. Included in $H_{j t}$ are household size and demographic composition, characteristics of the household head, and welfare status as measured by the log of household income per capita. The individual fixed factors in $v_{i}$ influence labor and time allocation constantly over time. A vector of province and time dummy variables $D_{p \times t}$ controls for province-specific macroeconomic shocks that may affect labor market demand. Lastly, $\varepsilon_{i j t}$ is an idiosyncratic error term.

Since our interest is in the population of women who do not migrate - those "left behind" - the sample for estimating this equation is confined to women who are present

\footnotetext{
${ }^{18}$ Since practically all women participate in household chores, we exclude this activity from the participation regressions.
} 
in all rounds of the data. Note also that since we are interested in drawing conclusions about this population only there are no selection problems at this level. Furthermore, for this same reason, the rate of attrition in the rest of the sample is not a concern for drawing inferences about non-migrant women.

While the specification in (1) may seem natural, it has a number of drawbacks. The objective of our analysis is to derive an unbiased estimate of, which the impact of a household member's migration on non-migrant women's time allocation. One concern with the above specification is simultaneity bias - the fact that the migration of household members may reflect joint decisions with a woman's labor allocation. For example, women's participation in agricultural work may facilitate a member's outmigration. ${ }^{19}$ Another concern is that household and individual characteristics in $X_{i j t}$ and $H_{j t}$ (such as marital status, fertility decisions, and elderly parents' living arrangements) may also be jointly determined with women's time allocation. To address these concerns, we use lagged migrant status and only include the initial value of individual and household characteristics. Furthermore, we use the panel structure of the data and apply first-differences to wipe out omitted variables that are time-invariant as contained in the $v_{i}$ error component. Finally, since prior changes in household conditions - for example a recent newborn or a change in marital status - could have an effect on lagged migration and outcomes, we also include changes in the lagged individual and household characteristics. $^{20}$

\footnotetext{
${ }^{19}$ The reference period for the labor time allocation questions is "last year", which exacerbates the reverse causality problem in the specification.

${ }^{20}$ We include lagged changes in marital status, household size and demographic composition. Changes in years of education are not included as they are unlikely to change over time and hence changes are likely to reflect measurement error. Given endogeneity concerns, we also exclude lagged changes in household income.
} 
Combining these observations, the specification we estimate takes the form:

$$
\begin{gathered}
\Delta Y_{i j t}=\beta_{0}+\beta_{1} \Delta M_{j t-1}+\Delta X_{i j t-1} \beta_{2}+\Delta H_{j t-1} \beta_{3}+X_{i j t-2} \beta_{4}+H_{j t-2} \beta_{5}+\Delta D_{p \times t} \\
+\Delta \varepsilon_{i j t}
\end{gathered}
$$

The identifying assumption needed for obtaining an unbiased estimate of $\beta_{1}$ in the above specification is that lagged changes in migration status are exogenous to currently observed changes in outcomes conditional on the controls. While this seems a reasonable assumption, the only reason to question it is if shocks that affect the change in household members' migration in previous survey rounds ( 2 to 4 years ago) have independent impacts on current changes in labor allocation. Demographic and weather shocks that affect the harvest are the most relevant types of shocks for rural households. However, our regressions include detailed demographic controls and a dummy for lagged health shocks to household members, and weather shocks have contemporaneous effects which lagging should deal with. So, the combination of fixed effects, the controls and the lagging, suggest that our estimates should not suffer from serious bias.

Note that this specification requires at least three consecutive observations for each non-migrant woman. In about 80 percent of cases, we have 4 observations. In this case, we can identify two changes over time - namely the change in outcome between 2000 and 2004 and that between 2004 and 2006 that results from a change in migration between 1997 and 2000, and between 2000 and 2004, respectively. For the other women, we create two panels with three consecutive observations each - one covering 1997 through 2004 and the other spanning 2000 through 2006.

In estimating equation (2), and in all subsequent regressions, we take account of potential serial correlation within villages by using clustered standard errors. We report 
robust standard errors clustered at the village level which allow for a common correlation among households within the same village and over time. Given the small number of observations over time we are unable to deal with idiosyncratic serial correlation at the household or individual level within villages.

The migration of a household member can be measured in different ways. First, we define a "migrant household" to be one that has at least one migrant and estimate an encompassing model where migration is treated as a yes or no and does not distinguish who, or how many migrate. We then examine children's (and separately sons and daughters), husband's and other members' migration separately, allowing the impacts to differ according to who migrates. For example, it could be that children remit less as they are saving more for their own futures whereas husbands plan to come back. Although we are unable to investigate this issue with our data, we can ascertain whether effects differ according to who migrates.

In the first specification, the change in a household's migration status $\left(\Delta M_{j t-1}\right)$ can take three values: +1 denotes that a household has no migrant at time $\mathrm{t}-2$ but has at least one at time t-1 (we label this scenario as having a new migrant(s)); 0 denotes the case of no change in the household's migration status between time t-2 and time t-1; and 1 the case where the household has a migrant member(s) at time $t-2$, but none at time $t-1$ (we term this situation as having a return migrant(s)). The above specification assumes that having a new migrant(s) has the equivalent reverse impact on left behind women's outcomes as having a return migrant(s). That is, outcomes such as labor allocation are fully adjustable in response to a household member's migration. However, the impacts of new migration and return migration may well be asymmetric, for example if intrahousehold labor allocation arrangements are made once when out-migration occurs but 
not remade upon return migration. If migration is a long-term arrangement, and return migration is often short-term, one would also expect left-behind women's labor allocation to be more responsive to new out-migration than to return migration. To test whether there are asymmetric impacts of new and return migration, we modify the specification in equation (2) and estimate the following:

$$
\begin{gathered}
\Delta Y_{i j t}=\gamma_{0}+\gamma_{1} I\left(\Delta M_{j t-1}\right)+\gamma_{2} I\left(-\Delta M_{j t-1}\right)+\Delta X_{i j t-1} \gamma_{3}+\Delta H_{j t-1} \gamma_{4}+X_{i j t-2} \gamma_{5} \\
+H_{j t-2} \gamma_{6}+\Delta D_{p \times t}+\Delta \varepsilon_{i j t}
\end{gathered}
$$

where $I(x)$ is the indicator function, such that $I(x)=1$ if $x>0$ and $I(x)=0$ otherwise. If return migration reverses the impacts of outmigration, then we expect $\gamma_{1}+\gamma_{2}=0$. The rejection of this null implies that new and return migration have symmetric impacts.

Given the importance of age in labor allocation as evidenced in the results in Section 4, we estimate the impacts of migration using both the total sample of nonmigrant women and subsamples stratified by age cohort.

\subsection{Results}

Tables 3 through 6 examine the impacts of living in a migrant household on the participation of non-migrant women in various activities and Tables 7 to 10 report impacts on the hours worked in those activities, for the encompassing model given in equation (3) and its various refinements. All regressions control for the same set of detailed household and individual characteristics although we report the coefficient estimates on the covariates only for the all-encompassing model (Tables 3 and 7). ${ }^{21}$ The others report the estimated coefficients on the migration status variable only since these are our main interest.

\footnotetext{
${ }^{21}$ We report the summary statistics for the explanatory variables in Appendix Table 1 . The sample means of time allocation and labor force participation for non-migrant women and men are reported in Appendix Table 3.
} 
Controlling for initial levels and changes in lagged household and individual characteristics, we find positive impacts on the participation of non-migrant women in agricultural work, and these effects are significant at the $1 \%$ level (Table 3). The probability of working on the farm is $6 \%$ higher for left-behind women. There are no signs of effects on participation in non-agricultural work. Disaggregating to look at this relationship by age cohorts and controlling for the same covariates, reveals that the impact on farm work is statistically significant only for the cohort of women aged 36 to 50 (Table 4). The estimated effects for the age cohorts 21 to 35, and 51 to 60 are not significantly different from that for women aged 36 to 50 but they are imprecisely estimated reflecting the smaller sample sizes for those cohorts.

When we allow impacts to differ according to who migrates, the results suggest that increased participation in farm work is due to children's migration (Table 5). The migration of offspring significantly raises the probability that women engage in farm work - by $7 \%$ in the overall sample, $6 \%$ for women aged 36 to 50 , and $10 \%$ for those aged 51 to 60 . This specification also suggests that a husband's migration reduces participation in wage labor by the 21 to 35 age cohort by about $8 \%$. Although it is somewhat less precisely estimated, this group's labor participation appears to be transferred to farm work. However, when we test for whether the impacts of children's migration are statistically different from those of a husband's migration, we find that they are not, even though children's migration can be more precisely estimated for the 36-60

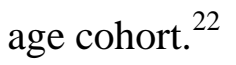

\footnotetext{
${ }^{22}$ We initially ran the regressions also separating out sons and daughters. However, statistically, we find no systematic difference due to the gender of the migrating child.
} 
Finally, the results in Table 6 suggest that the impacts of being left-behind are not reversed once migrant household members return. In particular, return migration is found to have a negative effect on non-migrant women's participation in non-agriculture activities - reducing the probability of partaking in family businesses by $5 \%$ in the overall sample (significant only at the $10 \%$ level) and by $16 \%$ for women in the 51 to 60 age cohort. This suggests that return migrants may aspire to off-farm self-employment, and supplant left-behind women's labor in family businesses.

Whether one participates in an activity or not is a rather blunt measure and we expect to see more response in the hours devoted to various activities. Tables 7 through 10 present the results with respect to hours worked, again for the various specifications. ${ }^{23}$ Turning first to the regressions on the entire sample of non-migrant women, we find no sign of impacts on total hours worked or on the time spent doing chores (Table 7). On average, left-behind women do not appear to have longer work days or reduced leisure as a result of household adult members going away for work. Conversely, there are no signs that leisure time has increased.

However, left-behind women may well be doing more strenuous work during those working hours. We find evidence of significant re-allocation effects across labor force activities. In particular, living in a migrant household has a statistically significant impact of close to 3 more hours worked in agriculture per week. Conversely, it reduces the hours worked off the farm by about the same amount: with around a third coming out of wage work and the rest out of work on the family business.

Unpacking these impacts, we find that the effects on the distribution of working hours across activities are most pronounced for the 36 to 50 age cohort reinforcing our

\footnotetext{
${ }^{23}$ We have not logged the dependent variable for these estimations due to the many zero hours.
} 
results in the case of participation (Table 8). This group sees a 2.4 hour weekly increase in time spent working on the farm and a reduction of 3.4 hours on non-agricultural work. However, women in the next cohort (age 51 to 60) see an even larger increase of 3.7 hours devoted to farm work.

In Table 9, the results are presented according to who in the household migrated. In line with our previous results on participation, positive and statistically significant impacts on the time devoted to farm work are primarily associated with the migration of children. Again, they are positive and statistically significant for women in the 36 to 60 age group. There is also a statistically significant effect of husband's migration on farm work hours for the cohort aged 21 to 35 who are for the most part still too young to have migrant children. Echoing our previous results, there are signs of reduced leisure time for older women linked to the migration of children. We find large though imprecisely estimated impacts on total hours worked by the 51-60 age group. Significant negative impacts on the hours worked outside agriculture are due both to husband's and children's migration. These effects are particularly large for wage labor.

Table 10 shows again that the effects of out and return migration are quite consistently not symmetric. When considering the entire sample, it is out-migration that results in hours re-allocated from non-farm activities to farm work. ${ }^{24}$ The patterns are a little less clear when we look at individual age cohorts. However, for the 21-35 age cohort, return migration appears to have almost as large a positive impact on the hours worked in agriculture as does out migration. It also leads to a pronounced and significant negative effect on time spent in the family business and conversely, a positive effect on

\footnotetext{
${ }^{24}$ We reject the null hypothesis that return and out migration have reverse impacts with a F-statistic of 6.02 and p-value 0.015 .
} 
time devoted to household chores. For the 36-50 age cohort, the decrease in nonagriculture working hours (particularly wage labor) due to out migration is not reversed by return migration.

We find that left-behind women increase their labor allocation to household agricultural production, but do they also gain status in the process by becoming the household's primary managers and decision makers in these activities? Using the same reduced form models we examine whether they are more likely to hold primary responsibility for household farming, fishing and livestock activities as a result of living in a migrant household. We find no impacts in this regard (Panel A in Table 11). ${ }^{25}$ Finally, we also look at various health outcomes as described above (Panel B in Table 11). ${ }^{26}$ We find no impacts on morbidity measured by incidence of illness in the last four weeks or in the past three months. Tested blood pressure is not affected by household migration status either. ${ }^{27}{ }^{28}$ There is no sign that self-reported health worsens as a result of a household member's migration. The results on the overweight status are difficult to explain - we find marginally significant and positive impacts on the probability of being overweight for the age group of 36-50; a negative impact for the 51-60 age cohort; and no

\footnotetext{
${ }^{25}$ These results may indicate that women prefer not to incur increased decision making responsibilities to avoid potential blame for failed tasks as some sociology studies have emphasized (Nelson 1992, Murphy 2004). However, they may well also indicate resistance on the part of male household members in relegating such responsibilities.

${ }^{26}$ There are some obvious data errors in the height and weight measures in the 2004 and 2006 waves. For individuals aged 22 and above, heights differed by more than 5 centimeters between survey waves for about $10 \%$ of the sample. For those observations, we replace the value with their 2000 height. We further dropped the observations with BMI less than 10 or greater than 50 . The overweight and underweight cutoffs apply only for individual aged 18 and above, therefore we don't estimate regressions for these outcomes for the 16-20 cohort.

${ }^{27}$ There is little variation in the measures of high and low blood pressure for the 16-20 age cohort, so we can't reliably estimate these two outcomes for this age group. The same is true for the measure of low blood pressure for the 61-70 age cohort.

${ }^{28}$ The results are similar when we use self-reported high blood pressure.
} 
impact for the other age groups. There is no sign that the probability of being underweight is affected by a household member's migration.

\subsection{What about left behind men?}

Some men also stay behind in rural areas while household members migrate. As for women, the proportion of non-migrant men living in migrant households increases between 1997 and 2006 for all age groups - from 7 to 29 percent for the 16 to 20 age cohort, 7 to 16 percent for the 21 to 35 cohort, 11 to 27 percent for those aged 36-50, 21 to 52 percent for the 51 to 60 cohort, and 11 to 41 percent for the oldest. Thus, older men are more likely to live in migrant households than younger men. Furthermore, the share of left behind men is lower than that for women in the younger cohorts but higher for the 50 plus cohorts. However, recall that more men are migrants. In general men are significantly more likely to be affected by a child's than by their spouse's absence.

Non-migrant men tend to work fewer total hours than their female counterparts (Appendix Table 3). They spend less time engaged in agriculture and in domestic production. Conversely, more of their working hours are devoted to family businesses and particularly, non-agricultural wage activities. This suggests that the pool of men and women who are not migrants are different. The men may choose not to migrate because of good local job opportunities, while the women stay in rural areas largely to look after the farm and household responsibilities.

Of interest is whether left-behind men also re-arrange their time and activities as a result of being left behind. Using the same variable definitions and specifications, we repeat the analysis for men. We find absolutely no sign of impacts on work behavior and time allocation on the part of men as a result of being left behind (Table 12). We also examine whether impacts are felt at the level of taking responsibility for household 
agricultural activities or on health outcomes, and here too find no evidence that anything alters for men as a result of living in a migrant household.

\section{Conclusions}

Our study reveals the complexities and ambiguities behind the dramatic labor market transition that China has been going through stemming from effects on work allocation within households. The transformation of China's economy is creating new non-farm work opportunities for some women in rural China, notably those who migrate. But this is not an unambiguous process whereby all rural women transit out of farming. Indeed, we have found that the non-migrant women left behind in rural areas, while other household members migrate, are doing more farm work than would have otherwise been the case. In stark contrast, we find no impacts at all on left-behind men.

The aggregate transformation of work during China's rapid economic development is being associated with a substantial re-allocation of traditional farm labor among women - the young doing much less and older women much more. Moreover, our results suggest that the re-allocation of left-behind women's time resulting from the migration of household members entails more hours in farm work at the cost of fewer hours in local off-farm work, with no sign of increasing decision-making responsibilities over the household's farming activities. In other words, this is not a simple process of labor re-allocation away from farming; instead, some women (the migrants) are doing less farm work while others (the left-behind) are doing more. We also find evidence that this is a persistent effect, and not just a temporary re-allocation. However, left-behind women's health appears not to be affected. 


\section{References}

Amuedo-Dorantes, C., Pozo, S., 2006. Migration, Remittances, and Male and Female Employment Patterns. American Economic Review: Papers and Proceedings 96(2), 222226.

Beine, M., Docquier, F., Rapoport, H., 2008. Brain Drain and Human Capital Formation in Developing Countries: Winners and Losers. The Economic Journal 118 (April), 631652.

Bourguignon, F.,Browning, M., Chiappori, P., Lechene, V.,1993. Incomes and Outcomes: A Structural Model of Intra-household Allocation. Journal of Political Economy 102(6), 285-307

Browning, M., Chiappori, P., 1998. Efficient Intra-household Allocations: A General Characterization and Empirical Tests. Econometrica 66(6),1231-1278.

Chen F., 2005. Employment Transitions and the Household Division of Labor in China. Social Forces 84(2), 831-851.

Chen, J, 2006a. Identifying Non-Cooperative Behavior Among Spouses: Child Outcomes in Migrant Sending Households. mimeo, Ohio State University.

Chen , J, 2006b. Migration and Imperfect Monitoring: Implications for Intra-household Allocation. American Economic Review: Papers and Proceedings 96(2): 227-231.

Davin, D.,, 1999. Internal Migration in Contemporary China, N.Y., N.Y.: St. Martin's Press.

de Brauw, A., Giles, J., 2008. Migrant Labor and the Welfare of Rural Households in the Developing World: Evidence from China. Policy Research Working Paper 4585, World Bank, Washington, D.C.

de Brauw, A., Li, Q., Liu, Q., Rozelle S., Zhang, L., 2008. Feminization of Agriculture in China? Myths Surrounding Women's Participation in Farming. The China Quarterly. 194(June), 327-348.

Deininger, K., Jin, S., forthcoming. Securing Property Rights in Transition: Lessons from Implementation of China's Rural Land Contracting Law. Journal of Economic Behavior and Organization.

Du, Y, Park, A.,Wang, S., 2005. Migration and Rural Poverty in China. Journal of Comparative Economics 33(4),688-709.

Duflo, E., 2003. Grandmothers and Granddaughters: Old Age Pension and Intrahousehold Allocation in South Africa. World Bank Economic Review 17 (1),1-25. 
Fan, C., 2003. Rural-urban Migration and Gender Division of Labor in Transitional China. International Journal of Urban and Regional Research 27(1), 24-47

Fan, C., 2004. Out to the City and Back to the Village: The Experiences and Contributions of Rural Women Migrating from Sichuan and Anhui. in Gaetano A., Jacka, T., eds. On the Move, Women in Rural-to-Urban Migration in Contemporary China. Columbia University Press, New York.

Fan, C., 2008. China on the Move: Migration, the State, and the Household, London and New York: Routledge.

Giles, J., Mu, R., 2007. Elder Parent Health and the Migration Decision of Adult Children: Evidence from Rural China. Demography, 265-288

Hildebrandt, N., McKenzie, D., 2005. The Effects of Migration on Child Health in Mexico. Economia 6(1), 257-289.

Liang, Z., Chen, Y.,2004. Migration and Gender in China: An Origin-Destination Linked Approach. Economic Development and Cultural Change 52(2), 423-43.

Lin, J., Wang, G., Zhao Y., 2003. Regional Inequality and Labor Transfers in China. Paper Prepared for D. Gale Johnson Memorial Conference, Chicago

Lokshin, M., Glinskaya, E., 2008. The Effects of Male Migration for Work on Employment Patterns of Females in Nepal. Policy Research Working Paper 4757, World Bank, Washington, DC.

Mendola, M., Carletto G., 2009. International Migration and Gender Differentials in the Home Labor Market: Evidence from Albania. Policy Research Working Paper 4900, World Bank, Washington, DC.

Murphy, R., 2004. The Impact of Labor Migration on the Well-Being and Agency of Rural Chinese Women: Cultural and Economic Contexts and the Life Course. in Gaetano A., Jacka T.,eds. On the Move, Women in Rural-to-Urban Migration in Contemporary China. Columbia University Press, New York.

Nelson, N., 1992. The Women who Have Left and Those who Have Stayed Behind: Rural-Urban Migration in Central and Western Kenya. in Chant S., Radcliffe, S., eds. Gender and Migration in Developing Countries, New York: Belhaven Press.

Rodriguez, E., Tiongson, E., 2001. Temporary Migration Overseas and Household Labor Supply: Evidence from Urban Philippines. International Migration Review 35(3), 709725.

Short, S., Chen, F., Entwisle, B., Zhai, F., 2002. Maternal Work and Child Care in China: A Multi-Method Analysis. Population and Development Review 28(1), 31-57. 
Thomas, D., 1994. Like Father, Like Son; Like Mother, Like Daughter: Parental Resources and Child Height. Journal of Human Resources 29(4), 950-988.

World Bank, 2009. From Poor Areas to Poor People: China's Evolving Poverty Reduction Agenda. World Bank: Washington, DC.

Woodruff, C., Zenteno, R., 2007. Migration Networks and Microenterprises in Mexico. Journal of Development Economics 82(2), 509-528.

Yang, D., 2008. International Migration, Remittances, and Household Investment:

Evidence from Philippine Migrants' Exchange Rate Shocks. The Economic Journal 118 (April), 591-630.

Zhang, L., de Brauw , A., Rozelle, S., 2004. China's Rural Labor Market Development and its Gender Implications. China Economic Review 15, 230-47.

Zhao, Y., 2002. Causes and Consequences of Return Migration: Recent Evidence from China. Journal of Comparative Economics 30, 376-394. 
Figure 1: Allocation of labor across activities by gender and age.

a) Migration rate by year, age and gender

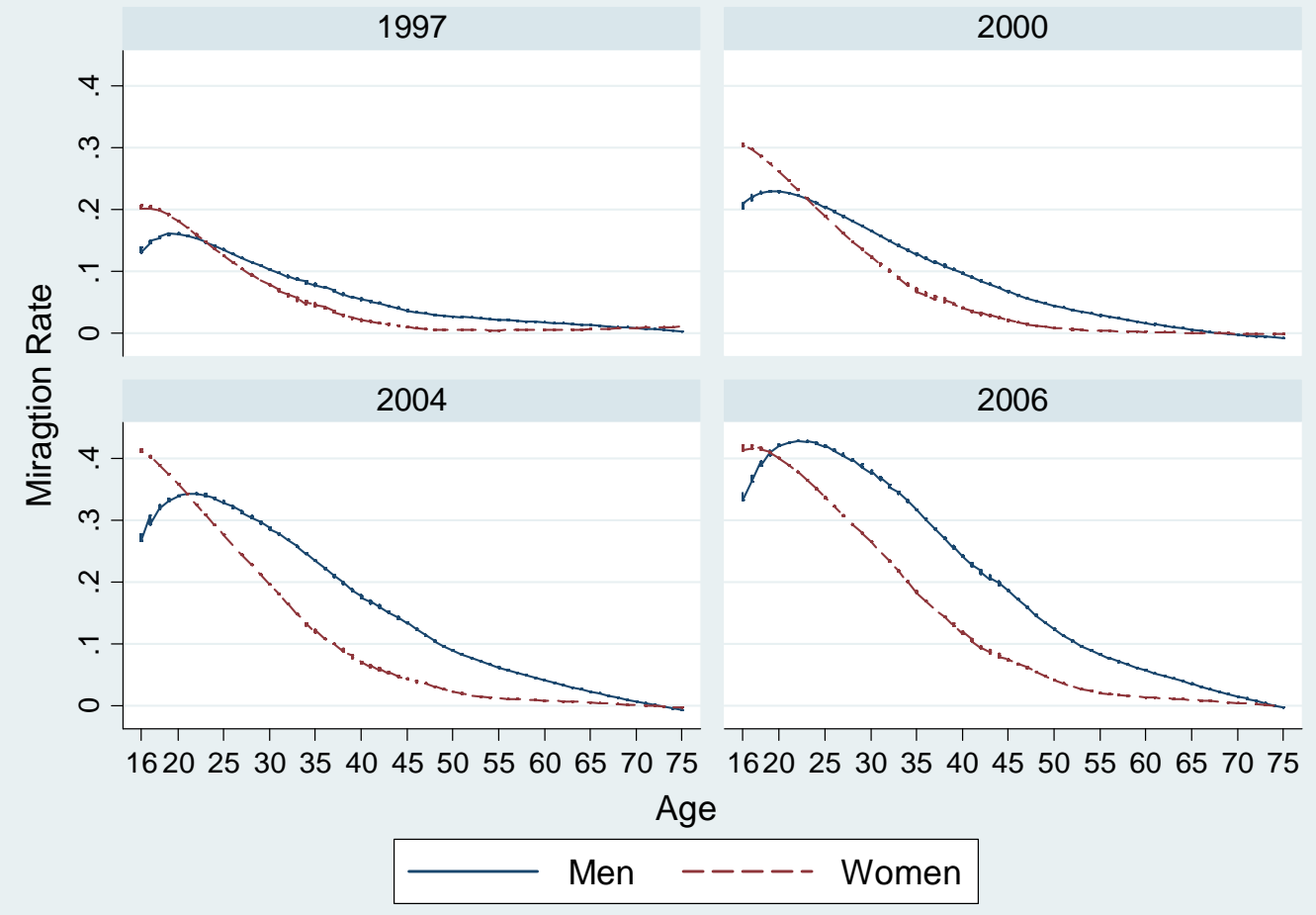

b) Share of labor force working in agriculture by year, age and gender

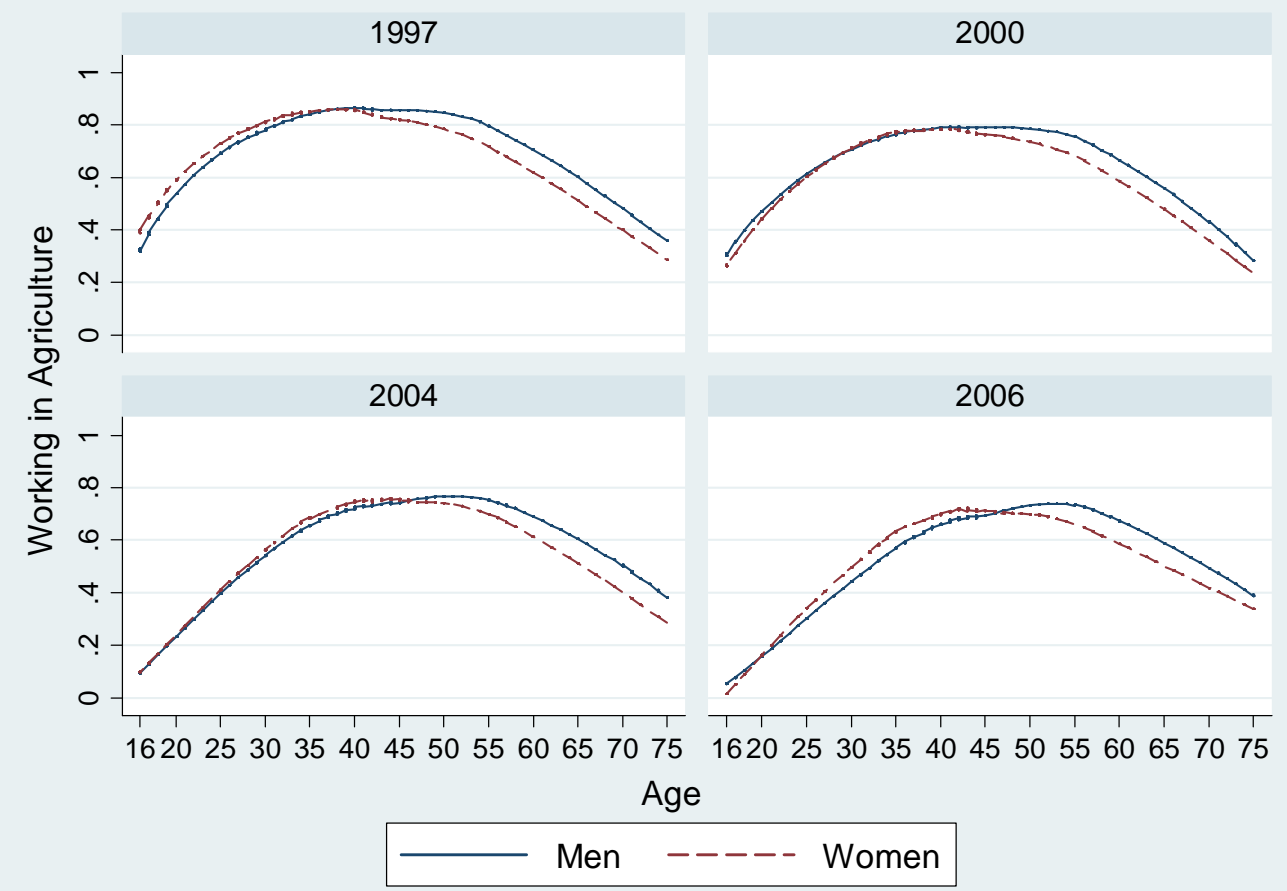


c) Share of labor force in local wage labor by year, age and gender

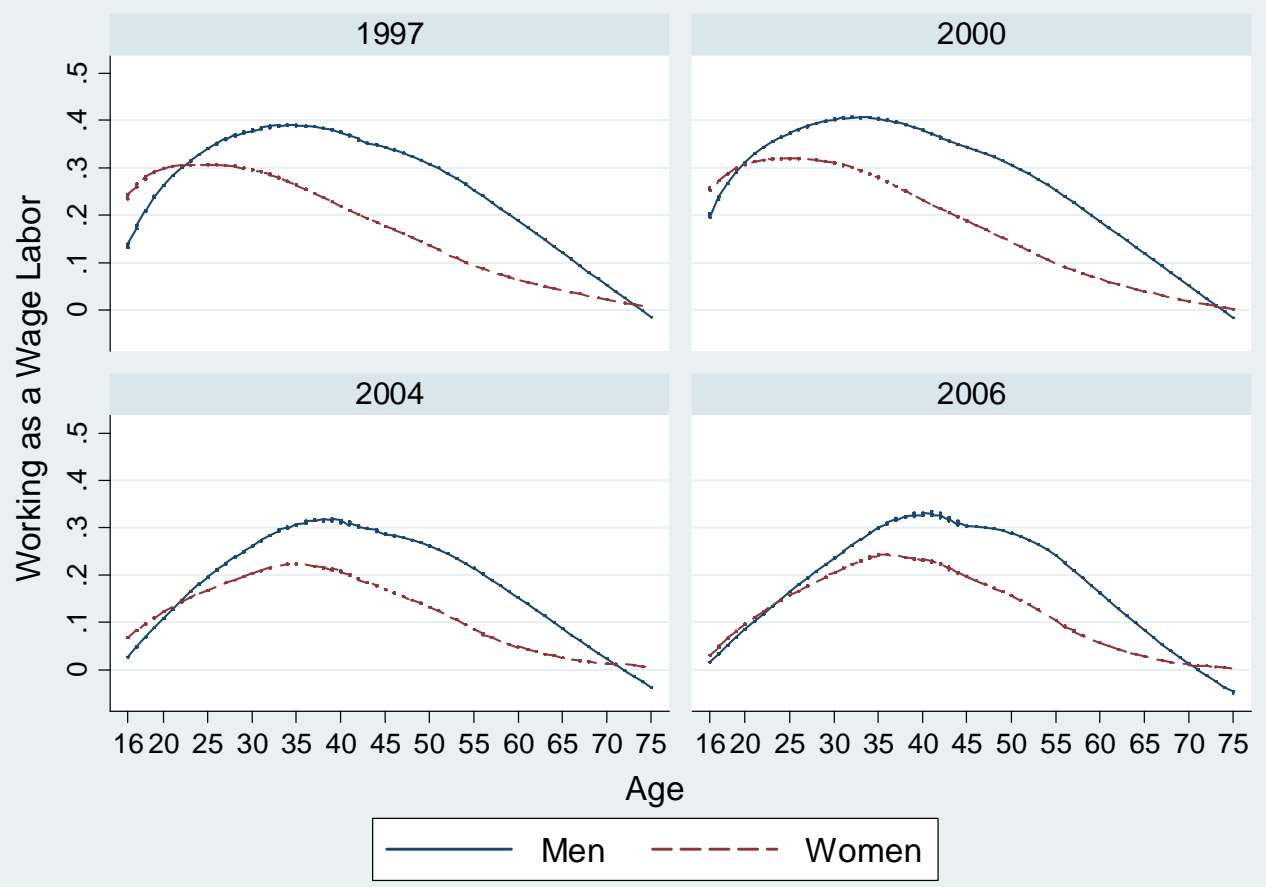

d) Share of labor force in family business by year and gender

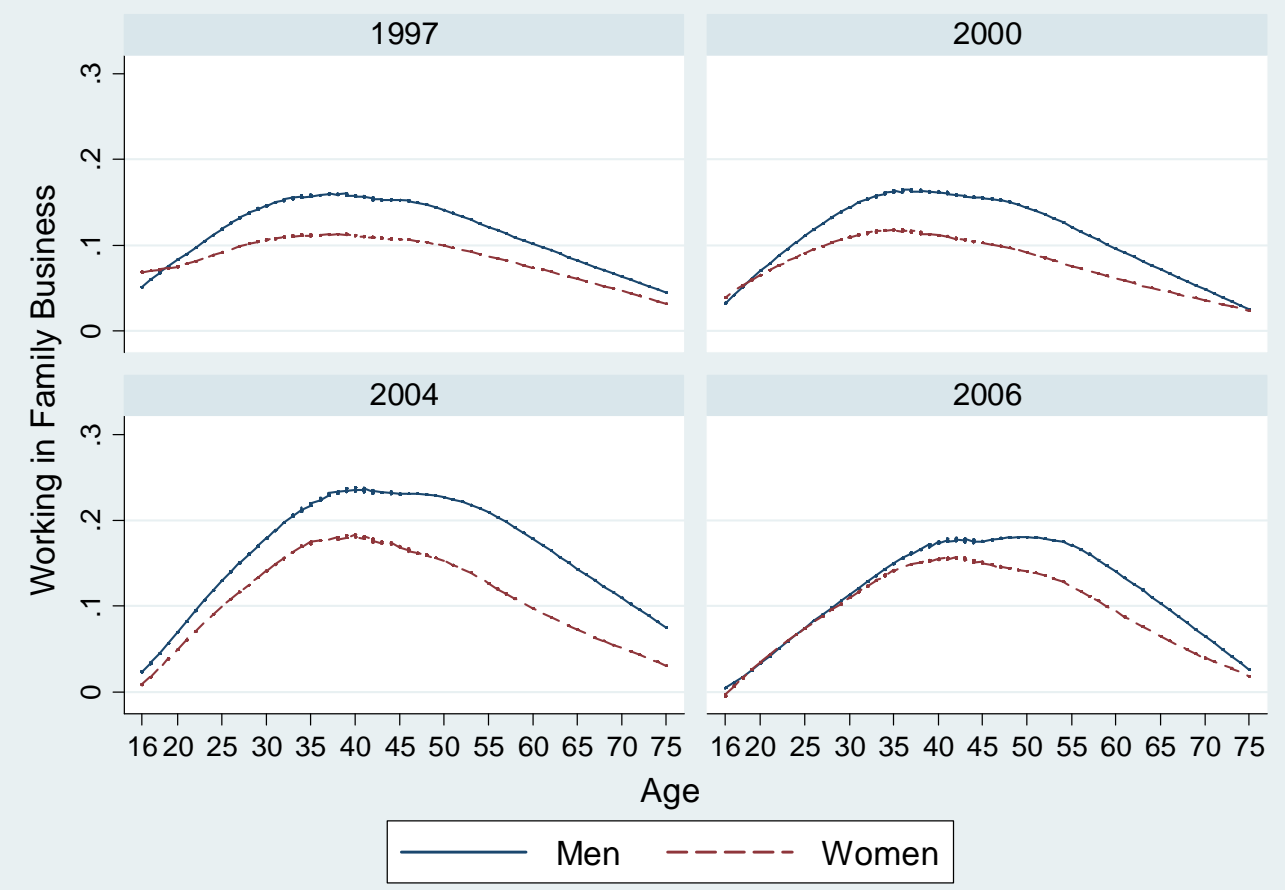


Table 1: Labor force participation and distribution across activities of rural men and women aged 16 to 70 , from 1997 to 2006

\begin{tabular}{|c|c|c|c|c|c|}
\hline & & 1997 & 2000 & 2004 & 2006 \\
\hline \multicolumn{6}{|l|}{ Rural men: } \\
\hline \multirow[t]{3}{*}{ Working } & $\%$ & 89.0 & 87.8 & 82.4 & 82.1 \\
\hline & age & 38.2 & 38.7 & 40.5 & 40.8 \\
\hline & education & 7.4 & 7.8 & 7.8 & 7.9 \\
\hline \multirow[t]{3}{*}{ Migrants } & $\%$ of labor force & 7.8 & 11.6 & 19.0 & 24.5 \\
\hline & age & 27.8 & 28.4 & 30.2 & 30.8 \\
\hline & education & 7.9 & 8.4 & 8.2 & 8.1 \\
\hline \multirow[t]{3}{*}{ Agriculture } & $\%$ of labor force & 76.6 & 70.7 & 60.9 & 55.3 \\
\hline & age & 38.9 & 39.7 & 43.6 & 45.2 \\
\hline & education & 7.3 & 7.7 & 7.7 & 7.9 \\
\hline \multirow[t]{3}{*}{ Local wage } & $\%$ of labor force & 32.3 & 34.1 & 23.5 & 23.5 \\
\hline & age & 36.2 & 36.2 & 40.1 & 41.5 \\
\hline & education & 8.8 & 8.9 & 9.1 & 9.2 \\
\hline \multirow[t]{3}{*}{ Family business } & $\%$ of labor force & 13.3 & 13.3 & 18.6 & 13.5 \\
\hline & age & 38.5 & 39.3 & 42.5 & 44.4 \\
\hline & education & 8.2 & 8.3 & 8.0 & 7.9 \\
\hline Obs. Number & & 3582 & 4026 & 4023 & 4273 \\
\hline \multicolumn{6}{|l|}{ Rural women: } \\
\hline \multirow[t]{3}{*}{ Working } & $\%$ & 85.9 & 82.1 & 75.1 & 73.4 \\
\hline & age & 38.0 & 38.8 & 40.8 & 41.1 \\
\hline & education & 5.6 & 6.2 & 6.1 & 6.4 \\
\hline \multirow[t]{3}{*}{ Migrants } & $\%$ of labor force & 5.6 & 8.2 & 11.6 & 14.9 \\
\hline & age & 23.1 & 23.6 & 25.1 & 26.9 \\
\hline & education & 7.8 & 8.4 & 7.7 & 7.8 \\
\hline \multirow[t]{3}{*}{ Agriculture } & $\%$ of labor force & 76.0 & 68.4 & 61.3 & 56.4 \\
\hline & age & 38.5 & 39.9 & 43.6 & 44.7 \\
\hline & education & 5.5 & 6.0 & 5.8 & 6.0 \\
\hline \multirow[t]{3}{*}{ Local wage } & $\%$ of labor force & 21.7 & 22.3 & 15.0 & 15.8 \\
\hline & age & 32.1 & 32.6 & 36.8 & 38.3 \\
\hline & education & 8.4 & 8.6 & 8.7 & 8.8 \\
\hline \multirow[t]{3}{*}{ Family business } & $\%$ of labor force & 9.8 & 9.5 & 13.4 & 11.5 \\
\hline & age & 38.3 & 38.3 & 41.8 & 43.4 \\
\hline & education & 6.6 & 7.2 & 6.7 & 7.1 \\
\hline Obs. Number & & 3445 & 3891 & 3849 & 4012 \\
\hline
\end{tabular}

Note: CHNS rural sample of men and women aged 16 to 70 years. 
Table 2: Non-migrant women in migrant households (\%)

\begin{tabular}{|c|c|c|c|c|c|c|c|c|}
\hline age $16-20$ & \multicolumn{2}{|c|}{1997} & \multicolumn{2}{|c|}{2000} & \multicolumn{2}{|c|}{2004} & \multicolumn{2}{|c|}{2006} \\
\hline living in migrant household & 11.1 & $(31.6)$ & 14.4 & $(35.2)$ & 26.9 & $(44.5)$ & 36.8 & $(48.4)$ \\
\hline parent(s) migrated & 5.3 & $(22.5)$ & 7.2 & $(26.0)$ & 11.7 & $(32.2)$ & 16.8 & $(37.5)$ \\
\hline sibling(s) migrated & 5.4 & $(22.6)$ & 6.1 & $(24.1)$ & 9.8 & $(29.9)$ & 21.2 & $(41.0)$ \\
\hline $\begin{array}{l}\text { obs. } \\
\text { age } 21-35\end{array}$ & \multicolumn{2}{|c|}{117} & \multicolumn{2}{|c|}{153} & \multicolumn{2}{|c|}{130} & \multicolumn{2}{|c|}{155} \\
\hline living in migrant household & 6.3 & $(24.3)$ & 12.4 & $(33.0)$ & 15.3 & $(36.1)$ & 21.0 & $(40.8)$ \\
\hline husband migrated & 3.4 & $(18.1)$ & 7.5 & $(26.5)$ & 10.1 & $(30.2)$ & 8.7 & $(28.3)$ \\
\hline child(ren) migrated & 0.2 & $(4.3)$ & 0.0 & 0.0 & 0.6 & $(7.9)$ & 0.0 & 0.0 \\
\hline $\begin{array}{l}\text { obs. } \\
\text { age } \mathbf{3 6 - 5 0}\end{array}$ & \multicolumn{2}{|c|}{649} & \multicolumn{2}{|c|}{466} & \multicolumn{2}{|c|}{248} & \multicolumn{2}{|c|}{186} \\
\hline living in migrant household & 18.3 & $(38.7)$ & 26.9 & $(44.4)$ & 40.5 & $(49.1)$ & 43.6 & $(49.6)$ \\
\hline husband migrated & 3.1 & $(17.4)$ & 5.4 & $(22.6)$ & 10.9 & $(31.2)$ & 11.8 & $(32.2)$ \\
\hline child(ren) migrated & 15.4 & $(36.1)$ & 24.3 & $(42.9)$ & 35.0 & $(47.7)$ & 39.4 & $(48.9)$ \\
\hline obs. & \multicolumn{2}{|c|}{821} & \multicolumn{2}{|c|}{840} & \multicolumn{2}{|c|}{716} & \multicolumn{2}{|c|}{635} \\
\hline \multicolumn{9}{|l|}{ age $51-60$} \\
\hline living in migrant household & 18.8 & $(39.1)$ & 26.6 & $(44.2)$ & 35.3 & $(47.9)$ & 44.1 & $(49.7)$ \\
\hline husband migrated & 1.2 & $(11.0)$ & 1.0 & $(10.2)$ & 3.2 & $(17.6)$ & 6.6 & $(24.8)$ \\
\hline child(ren) migrated & 17.1 & $(37.7)$ & 23.9 & $(42.7)$ & 32.6 & $(46.9)$ & 39.4 & $(48.9)$ \\
\hline age $>61$ & \multicolumn{2}{|c|}{336} & \multicolumn{2}{|c|}{399} & \multicolumn{2}{|c|}{447} & \multicolumn{2}{|c|}{497} \\
\hline living in migrant household & 7.3 & $(26.1)$ & 12.1 & $(32.7)$ & 24.8 & $(43.3)$ & 30.4 & $(46.1)$ \\
\hline husband migrated & 0.9 & $(9.6)$ & 0.4 & $(6.5)$ & 0.4 & $(6.6)$ & 2.5 & $(15.6)$ \\
\hline child(ren) migrated & 4.1 & $(20.0)$ & 9.2 & $(29.0)$ & 21.3 & $(41.0)$ & 24.7 & $(43.2)$ \\
\hline obs. & \multicolumn{2}{|c|}{219} & \multicolumn{2}{|c|}{240} & \multicolumn{2}{|c|}{250} & \multicolumn{2}{|c|}{270} \\
\hline
\end{tabular}




\section{Table 3: First difference estimates of left behind women's labor force participation in various activities}

\begin{tabular}{|c|c|c|c|c|}
\hline & $\begin{array}{l}\text { Participation } \\
\text { in agriculture }\end{array}$ & $\begin{array}{l}\text { Participation } \\
\text { in non-ag. }\end{array}$ & $\begin{array}{l}\text { Participation } \\
\text { in wage labor }\end{array}$ & $\begin{array}{c}\text { Participation } \\
\text { in family } \\
\text { business }\end{array}$ \\
\hline \multirow[t]{2}{*}{ Migrant household status (lagged) } & $0.058 * * *$ & -0.004 & -0.002 & -0.002 \\
\hline & $(0.021)$ & $(0.028)$ & $(0.010)$ & $(0.028)$ \\
\hline \multirow[t]{2}{*}{$\begin{array}{l}\text { Household member has bad health } \\
\text { (lagged) }\end{array}$} & -0.005 & -0.038 & -0.004 & -0.025 \\
\hline & $(0.015)$ & $(0.025)$ & $(0.012)$ & $(0.025)$ \\
\hline \multirow{2}{*}{$\begin{array}{l}\text { Change in woman's marital status } \\
\text { (lagged) }\end{array}$} & $0.217 * * *$ & -0.064 & -0.010 & $-0.057 *$ \\
\hline & $(0.030)$ & $(0.041)$ & $(0.022)$ & $(0.033)$ \\
\hline \multirow{2}{*}{$\begin{array}{l}\text { Change in the number girls aged } 0-6 \\
\text { (lagged) }\end{array}$} & 0.027 & 0.053 & -0.014 & 0.047 \\
\hline & $(0.030)$ & $(0.051)$ & $(0.023)$ & $(0.047)$ \\
\hline \multirow{2}{*}{$\begin{array}{l}\text { Change in the number of boys aged } 0-6 \\
\text { (lagged) }\end{array}$} & $0.049^{* *}$ & 0.008 & 0.004 & 0.002 \\
\hline & $(0.024)$ & $(0.040)$ & $(0.017)$ & $(0.038)$ \\
\hline \multirow{2}{*}{$\begin{array}{l}\text { Change in the number of girls aged 7-15 } \\
\text { (lagged) }\end{array}$} & -0.012 & 0.006 & -0.018 & 0.026 \\
\hline & $(0.021)$ & $(0.032)$ & $(0.014)$ & $(0.031)$ \\
\hline \multirow{2}{*}{$\begin{array}{l}\text { Change in the number of boys aged 7-15 } \\
\text { (lagged) }\end{array}$} & -0.022 & 0.004 & 0.012 & -0.011 \\
\hline & $(0.019)$ & $(0.030)$ & $(0.015)$ & $(0.027)$ \\
\hline \multirow{2}{*}{$\begin{array}{l}\text { Change in the number of elderly women } \\
\text { aged } 60 \text { and above (lagged) }\end{array}$} & -0.010 & 0.064 & 0.018 & 0.042 \\
\hline & $(0.034)$ & $(0.042)$ & $(0.023)$ & $(0.042)$ \\
\hline \multirow{2}{*}{$\begin{array}{l}\text { Change in the number of elderly men } \\
\text { aged } 60 \text { and above (lagged) }\end{array}$} & -0.035 & 0.022 & 0.008 & 0.015 \\
\hline & $(0.030)$ & $(0.043)$ & $(0.015)$ & $(0.042)$ \\
\hline \multirow[t]{2}{*}{ Change in h'hold size (lagged) } & -0.003 & 0.001 & -0.002 & 0.003 \\
\hline & $(0.004)$ & $(0.006)$ & $(0.002)$ & $(0.006)$ \\
\hline \multirow[t]{2}{*}{ Age $16-20$ in initial year } & 0.072 & -0.022 & -0.004 & -0.015 \\
\hline & $(0.083)$ & $(0.088)$ & $(0.045)$ & $(0.082)$ \\
\hline \multirow[t]{2}{*}{ Age $21-25$ in initial year } & 0.080 & 0.013 & -0.011 & 0.030 \\
\hline & $(0.072)$ & $(0.063)$ & $(0.033)$ & $(0.059)$ \\
\hline \multirow[t]{2}{*}{ Age $26-30$ in initial year } & $0.181 * * *$ & -0.001 & -0.007 & 0.007 \\
\hline & $(0.059)$ & $(0.051)$ & $(0.024)$ & $(0.051)$ \\
\hline \multirow[t]{2}{*}{ Age $31-35$ in initial year } & $0.222 * * *$ & 0.009 & 0.011 & 0.006 \\
\hline & $(0.057)$ & $(0.053)$ & $(0.027)$ & $(0.050)$ \\
\hline \multirow[t]{2}{*}{ Age $36-40$ in initial year } & $0.218 * * *$ & 0.060 & $0.038^{*}$ & 0.022 \\
\hline & $(0.060)$ & $(0.050)$ & $(0.022)$ & $(0.049)$ \\
\hline \multirow[t]{2}{*}{ Age $41-45$ in initial year } & $0.203 * * *$ & 0.069 & $0.029 *$ & 0.060 \\
\hline & $(0.055)$ & $(0.049)$ & $(0.017)$ & $(0.047)$ \\
\hline \multirow[t]{2}{*}{ Age $46-50$ in initial year } & $0.184 * * *$ & 0.052 & 0.007 & 0.055 \\
\hline & $(0.051)$ & $(0.052)$ & $(0.018)$ & $(0.051)$ \\
\hline \multirow[t]{2}{*}{ Age 51-55 in initial year } & $0.117 * *$ & 0.022 & 0.012 & 0.012 \\
\hline & $(0.057)$ & $(0.048)$ & $(0.016)$ & $(0.048)$ \\
\hline Age $56-60$ in initial year & 0.064 & 0.085 & 0.021 & 0.083 \\
\hline
\end{tabular}




\begin{tabular}{|c|c|c|c|c|}
\hline & $(0.050)$ & $(0.058)$ & $(0.024)$ & $(0.059)$ \\
\hline \multirow[t]{2}{*}{ Years of schooling in initial year } & 0.001 & 0.002 & $0.003^{*}$ & 0.000 \\
\hline & $(0.003)$ & $(0.003)$ & $(0.001)$ & $(0.003)$ \\
\hline \multirow[t]{2}{*}{ Years of schooling squared } & $-0.000 *$ & -0.000 & $-0.000 * * *$ & 0.000 \\
\hline & $(0.000)$ & $(0.000)$ & $(0.000)$ & $(0.000)$ \\
\hline \multirow{2}{*}{$\begin{array}{l}\text { Years of schooling of head in initial } \\
\text { year }\end{array}$} & $-0.005^{* *}$ & -0.004 & -0.001 & -0.003 \\
\hline & $(0.002)$ & $(0.003)$ & $(0.002)$ & $(0.003)$ \\
\hline \multirow[t]{2}{*}{ Age of household head in initial year } & $-0.004 * * *$ & -0.002 & -0.001 & -0.002 \\
\hline & 0.001 & 0.002 & $0.003^{*}$ & 0.000 \\
\hline \multirow[t]{2}{*}{ Minority household } & $0.092 * *$ & -0.033 & -0.026 & -0.015 \\
\hline & $(0.041)$ & $(0.040)$ & $(0.033)$ & $(0.032)$ \\
\hline \multirow[t]{2}{*}{ Household size in initial year } & $-0.009^{*}$ & -0.003 & -0.003 & -0.001 \\
\hline & $(0.005)$ & $(0.005)$ & $(0.002)$ & $(0.005)$ \\
\hline \multirow[t]{2}{*}{ Number of girls $0-6$ in initial year } & 0.036 & 0.063 & 0.010 & 0.046 \\
\hline & $(0.034)$ & $(0.046)$ & $(0.020)$ & $(0.044)$ \\
\hline \multirow[t]{2}{*}{ Number of boys $0-6$ in initial year } & $0.050^{*}$ & 0.048 & -0.004 & 0.050 \\
\hline & $(0.028)$ & $(0.035)$ & $(0.019)$ & $(0.034)$ \\
\hline \multirow[t]{2}{*}{ Number of girls 7-15 in initial year } & 0.010 & 0.020 & -0.006 & 0.024 \\
\hline & $(0.017)$ & $(0.019)$ & $(0.010)$ & $(0.019)$ \\
\hline \multirow[t]{2}{*}{ Number of boys 7-15 in initial year } & -0.005 & 0.034 & $0.023 * *$ & 0.018 \\
\hline & $(0.023)$ & $(0.023)$ & $(0.010)$ & $(0.022)$ \\
\hline \multirow[t]{2}{*}{ Number of elderly women in initial year } & 0.011 & $0.068 * *$ & 0.010 & $0.055^{*}$ \\
\hline & $(0.026)$ & $(0.028)$ & $(0.013)$ & $(0.031)$ \\
\hline \multirow[t]{2}{*}{ Number of elderly men in initial year } & -0.011 & -0.039 & -0.006 & -0.029 \\
\hline & $(0.033)$ & $(0.033)$ & $(0.018)$ & $(0.038)$ \\
\hline \multirow[t]{2}{*}{ Never married in initial year } & $-0.240 * * *$ & -0.033 & 0.017 & -0.035 \\
\hline & $(0.045)$ & $(0.062)$ & $(0.035)$ & $(0.054)$ \\
\hline \multirow[t]{2}{*}{ (log) Income per capita in initial year } & $-0.041 * * *$ & 0.015 & -0.004 & 0.016 \\
\hline & $(0.011)$ & $(0.011)$ & $(0.004)$ & $(0.010)$ \\
\hline \multirow[t]{2}{*}{ Constant } & $1.265^{* * *}$ & -0.070 & $0.100^{*}$ & -0.134 \\
\hline & $(0.132)$ & $(0.135)$ & $(0.056)$ & $(0.126)$ \\
\hline Number of observations & 3,340 & 3,340 & 3,340 & 3,340 \\
\hline $\mathrm{R}^{2}$ & 0.166 & 0.049 & 0.029 & 0.049 \\
\hline
\end{tabular}

Notes: The sample consists of all women who are present in at least three consecutive survey rounds. Participation in a labor force activity is a binary variable equal to 1 if the respondent reported being engaged or having positive working hours in the activity and 0 otherwise. Province/year interactions are included in the regressions but not reported. Standard errors are clustered at the village level. * denotes significance at $10 \%$ level; $* *$ denotes significance at $5 \%$ level; and $* * *$ denotes significance at $1 \%$ level. 
Table 4: First difference estimates on left behind women's labor force participation by initial age cohort

\begin{tabular}{lccccc}
\hline & Age16-20 & Age 21-35 & Age 36-50 & Age 51-60 & Age 61 -70 \\
& $\begin{array}{l}\text { A.008 } \\
\text { Participation in agriculture }\end{array}$ & 0.063 & $0.055^{* *}$ & 0.062 & 0.068 \\
& 182 & 826 & 1,478 & 683 & 171 \\
Obs. No & 0.114 & 0.032 & -0.030 & 0.032 & 0.024 \\
$\begin{array}{l}\text { Participation in non- } \\
\text { agriculture }\end{array}$ & $(0.195)$ & $(0.061)$ & $(0.037)$ & $(0.051)$ & $(0.149)$ \\
& 182 & 826 & 1,478 & 683 & 171 \\
$\begin{array}{l}\text { Obs. No } \\
\text { Participation in wage labor }\end{array}$ & 0.035 & -0.026 & -0.010 & 0.015 & -0.039 \\
& $(0.131)$ & $(0.030)$ & $(0.014)$ & $(0.017)$ & $(0.038)$ \\
$\begin{array}{l}\text { Obs. No } \\
\text { Participation in family }\end{array}$ & 182 & 826 & 1,478 & 683 & 171 \\
business & 0.064 & 0.044 & -0.031 & 0.041 & 0.024 \\
& $(0.125)$ & $(0.068)$ & $(0.033)$ & $(0.049)$ & $(0.149)$ \\
Obs. No & 182 & 826 & 1,886 & 683 & 171 \\
\hline
\end{tabular}

Notes: The sample consists of all women who are present in at least three consecutive survey rounds. Coefficients on lagged household migration status are reported. Other variables included but not reported are the same as are listed in Table 3 along with province/year interactions. Standard errors are clustered at the village level. * denotes significance at $10 \%$ level; $* *$ denotes significance at $5 \%$ level; and $* * *$ denotes significance at $1 \%$ level. 
Table 5: Impacts of different household members' migration on left behind women's labor force participation

\begin{tabular}{|c|c|c|c|c|}
\hline & $\begin{array}{l}\text { Participation } \\
\text { in agriculture }\end{array}$ & $\begin{array}{c}\text { Participation in } \\
\text { non-ag. }\end{array}$ & $\begin{array}{l}\text { Participation } \\
\text { in wage labor }\end{array}$ & $\begin{array}{l}\text { Participation in } \\
\text { family business }\end{array}$ \\
\hline \multicolumn{5}{|l|}{ Total Sample } \\
\hline Children migrated & $\begin{array}{c}0.073 * * * * \\
(0.023)\end{array}$ & $\begin{array}{l}-0.011 \\
(0.030)\end{array}$ & $\begin{array}{c}0.006 \\
(0.012)\end{array}$ & $\begin{array}{l}-0.012 \\
(0.029)\end{array}$ \\
\hline Husband migrated & $\begin{array}{c}0.041 \\
(0.036)\end{array}$ & $\begin{array}{l}-0.021 \\
(0.049)\end{array}$ & $\begin{array}{l}-0.040 \\
(0.026)\end{array}$ & $\begin{array}{c}0.005 \\
(0.048)\end{array}$ \\
\hline Other migrated & $\begin{array}{c}0.009 \\
(0.061)\end{array}$ & $\begin{array}{c}0.044 \\
(0.073)\end{array}$ & $\begin{array}{c}0.035 \\
(0.029)\end{array}$ & $\begin{array}{l}-0.001 \\
(0.071)\end{array}$ \\
\hline \multicolumn{5}{|l|}{ Age 16-20 } \\
\hline Other migrated & $\begin{array}{l}-0.008 \\
(0.168)\end{array}$ & $\begin{array}{c}0.114 \\
(0.195)\end{array}$ & $\begin{array}{c}0.035 \\
(0.131)\end{array}$ & $\begin{array}{c}0.064 \\
(0.125)\end{array}$ \\
\hline \multicolumn{5}{|l|}{ Age 21-35 } \\
\hline Husband migrated & $\begin{array}{c}0.079 \\
(0.049)\end{array}$ & $\begin{array}{l}-0.013 \\
(0.082)\end{array}$ & $\begin{array}{l}-0.078^{*} \\
(0.047)\end{array}$ & $\begin{array}{c}0.051 \\
(0.087)\end{array}$ \\
\hline Other migrated & $\begin{array}{c}0.048 \\
(0.088)\end{array}$ & $\begin{array}{c}0.076 \\
(0.088)\end{array}$ & $\begin{array}{c}0.028 \\
(0.040)\end{array}$ & $\begin{array}{c}0.038 \\
(0.096)\end{array}$ \\
\hline \multicolumn{5}{|l|}{ Age 36-50 } \\
\hline Children migrated & $\begin{array}{c}0.059 * * \\
(0.026)\end{array}$ & $\begin{array}{l}-0.017 \\
(0.044)\end{array}$ & $\begin{array}{c}0.001 \\
(0.015)\end{array}$ & $\begin{array}{l}-0.029 \\
(0.040)\end{array}$ \\
\hline Husband migrated & $\begin{array}{c}0.023 \\
(0.035)\end{array}$ & $\begin{array}{l}-0.055 \\
(0.054)\end{array}$ & $\begin{array}{l}-0.023 \\
(0.030)\end{array}$ & $\begin{array}{l}-0.041 \\
(0.047)\end{array}$ \\
\hline Other migrated & $\begin{array}{c}0.001 \\
(0.117)\end{array}$ & $\begin{array}{l}-0.130 \\
(0.126)\end{array}$ & $\begin{array}{c}0.005 \\
(0.025)\end{array}$ & $\begin{array}{l}-0.035 \\
(0.086)\end{array}$ \\
\hline \multicolumn{5}{|l|}{ Age 51-60 } \\
\hline Children migrated & $\begin{array}{l}0.099 * * \\
(0.046)\end{array}$ & $\begin{array}{c}0.019 \\
(0.052)\end{array}$ & $\begin{array}{l}0.026^{*} \\
(0.016)\end{array}$ & $\begin{array}{c}0.018 \\
(0.050)\end{array}$ \\
\hline Husband migrated & $\begin{array}{l}-0.225 \\
(0.228)\end{array}$ & $\begin{array}{c}0.056 \\
(0.253)\end{array}$ & $\begin{array}{l}-0.159 \\
(0.127)\end{array}$ & $\begin{array}{c}0.202 \\
(0.186)\end{array}$ \\
\hline Other migrated & $\begin{array}{c}0.029 \\
(0.126)\end{array}$ & $\begin{array}{l}-0.041 \\
(0.184)\end{array}$ & $\begin{array}{c}0.022 \\
(0.015)\end{array}$ & $\begin{array}{l}-0.051 \\
(0.182)\end{array}$ \\
\hline Age 61-70 & & & & \\
\hline Children migrated & $\begin{array}{l}-0.042 \\
(0.162)\end{array}$ & $\begin{array}{l}-0.014 \\
(0.120)\end{array}$ & $\begin{array}{l}-0.021 \\
(0.029)\end{array}$ & $\begin{array}{l}-0.014 \\
(0.120)\end{array}$ \\
\hline Other migrated & $\begin{array}{c}0.251 \\
(0.373)\end{array}$ & $\begin{array}{c}0.163 \\
(0.344)\end{array}$ & $\begin{array}{c}0.020 \\
(0.049)\end{array}$ & $\begin{array}{c}0.163 \\
(0.344)\end{array}$ \\
\hline
\end{tabular}

Notes: The sample consists of all women who are present in at least three consecutive survey rounds. Migration variables are valued at a one period lag. Other variables included but not reported are the same as are listed in Table 3 along with province/year interactions. Standard errors are clustered at the village level. $*$ denotes significance at $10 \%$ level; ** denotes significance at $5 \%$ level; and $* * *$ denotes significance at $1 \%$ level. 
Table 6: Impacts of out versus return migration on left behind women's labor force participation

\begin{tabular}{|c|c|c|c|c|}
\hline & $\begin{array}{c}\text { Participation in } \\
\text { agriculture }\end{array}$ & $\begin{array}{l}\text { Participation } \\
\text { in non-ag. }\end{array}$ & $\begin{array}{l}\text { Participation } \\
\text { in wage labor }\end{array}$ & $\begin{array}{l}\text { Participation } \\
\text { in family } \\
\text { business }\end{array}$ \\
\hline \multicolumn{5}{|l|}{ Total } \\
\hline Return migration & $\begin{array}{l}-0.002 \\
(0.017)\end{array}$ & $\begin{array}{l}-0.032 \\
(0.030)\end{array}$ & $\begin{array}{c}0.006 \\
(0.014)\end{array}$ & $\begin{array}{l}-0.048^{*} \\
(0.028)\end{array}$ \\
\hline Out migration & $\begin{array}{c}0.039 \\
(0.027)\end{array}$ & $\begin{array}{l}-0.013 \\
(0.036)\end{array}$ & $\begin{array}{c}0.021 \\
(0.017)\end{array}$ & $\begin{array}{l}-0.023 \\
(0.036)\end{array}$ \\
\hline \multicolumn{5}{|l|}{ Age 16-20 } \\
\hline Return migration & $\begin{array}{l}-0.183 \\
(0.136)\end{array}$ & $\begin{array}{c}0.142 \\
(0.190)\end{array}$ & $\begin{array}{c}0.042 \\
(0.145)\end{array}$ & $\begin{array}{c}0.088 \\
(0.131)\end{array}$ \\
\hline Out migration & $\begin{array}{c}0.042 \\
(0.228)\end{array}$ & $\begin{array}{c}0.190 \\
(0.343)\end{array}$ & $\begin{array}{c}0.116 \\
(0.207)\end{array}$ & $\begin{array}{c}0.050 \\
(0.224)\end{array}$ \\
\hline \multicolumn{5}{|l|}{ Age 21-35 } \\
\hline Return migration & $\begin{array}{c}0.045 \\
(0.045)\end{array}$ & $\begin{array}{l}-0.043 \\
(0.068)\end{array}$ & $\begin{array}{c}0.024 \\
(0.047)\end{array}$ & $\begin{array}{l}-0.084 \\
(0.062)\end{array}$ \\
\hline Out migration & $\begin{array}{c}0.071 \\
(0.058)\end{array}$ & $\begin{array}{c}0.001 \\
(0.078)\end{array}$ & $\begin{array}{c}0.026 \\
(0.023)\end{array}$ & $\begin{array}{l}-0.021 \\
(0.090)\end{array}$ \\
\hline \multicolumn{5}{|l|}{ Age 36-50 } \\
\hline Return migration & $\begin{array}{c}0.012 \\
(0.022)\end{array}$ & $\begin{array}{c}0.004 \\
(0.037)\end{array}$ & $\begin{array}{c}0.015 \\
(0.015)\end{array}$ & $\begin{array}{l}-0.023 \\
(0.035)\end{array}$ \\
\hline Out migration & $\begin{array}{c}0.040 \\
(0.030)\end{array}$ & $\begin{array}{l}-0.008 \\
(0.052)\end{array}$ & $\begin{array}{c}0.019 \\
(0.025)\end{array}$ & $\begin{array}{l}-0.028 \\
(0.046)\end{array}$ \\
\hline \multicolumn{5}{|l|}{ Age 51-60 } \\
\hline Return migration & $\begin{array}{l}-0.061 \\
(0.048)\end{array}$ & $\begin{array}{l}-0.140 * \\
(0.072)\end{array}$ & $\begin{array}{l}-0.019 \\
(0.028)\end{array}$ & $\begin{array}{c}-0.164 * * \\
(0.072)\end{array}$ \\
\hline Out migration & $\begin{array}{c}0.029 \\
(0.054)\end{array}$ & $\begin{array}{l}-0.046 \\
(0.062)\end{array}$ & $\begin{array}{c}0.020 \\
(0.026)\end{array}$ & $\begin{array}{l}-0.052 \\
(0.061)\end{array}$ \\
\hline \multicolumn{5}{|l|}{ Age $61-70$} \\
\hline Return migration & $\begin{array}{c}0.007 \\
(0.097)\end{array}$ & $\begin{array}{c}0.036 \\
(0.121)\end{array}$ & $\begin{array}{c}0.018 \\
(0.017)\end{array}$ & $\begin{array}{c}0.036 \\
(0.121)\end{array}$ \\
\hline Out migration & $\begin{array}{c}0.024 \\
(0.241)\end{array}$ & $\begin{array}{l}0.071 \\
(0.315)\end{array}$ & $\begin{array}{l}-0.117 \\
(0.106)\end{array}$ & $\begin{array}{c}0.071 \\
(0.315)\end{array}$ \\
\hline
\end{tabular}

Notes: The sample consists of all women who are present in at least three consecutive survey rounds. Migration variables are valued at a one period lag. Out migration is defined as 1 if at least one household member has migrated out for work from time $\mathrm{t}-2$ to time $\mathrm{t}-1$, and 0 otherwise. Return migration is defined as 1 if at least one household member has returned from work-related migration from time t-2 to time t-1. Other variables included in the regressions but not reported are the same as are listed in Table 3 along with province/year interactions. Standard errors are clustered at the village level. * denotes significance at $10 \%$ level; $* *$ denotes significance at $5 \%$ level; and $* * *$ denotes significance at $1 \%$ level. 
Table 7: First difference estimates of left behind women's weekly working hours in various activities

\begin{tabular}{|c|c|c|c|c|c|c|}
\hline & $\begin{array}{l}\text { Total hours } \\
\text { worked }\end{array}$ & $\begin{array}{l}\text { Hours in } \\
\text { agriculture }\end{array}$ & $\begin{array}{l}\text { Hours in non- } \\
\text { agriculture }\end{array}$ & $\begin{array}{c}\text { Hours in } \\
\text { wage labor }\end{array}$ & $\begin{array}{l}\text { Hours in } \\
\text { family business }\end{array}$ & $\begin{array}{c}\text { Hours in } \\
\text { household } \\
\text { chores }\end{array}$ \\
\hline Migrant household (lagged) & $\begin{array}{c}0.140 \\
(1.193)\end{array}$ & $\begin{array}{c}2.866^{* * * *} \\
(0.852)\end{array}$ & $\begin{array}{c}-2.542 * * * \\
(0.700)\end{array}$ & $\begin{array}{l}-0.720 * \\
(0.418)\end{array}$ & $\begin{array}{c}-1.762 * * * \\
(0.552)\end{array}$ & $\begin{array}{l}-0.097 \\
(0.608)\end{array}$ \\
\hline Household member has bad health (lagged) & $\begin{array}{l}-1.016 \\
(0.952)\end{array}$ & $\begin{array}{l}-0.458 \\
(0.597)\end{array}$ & $\begin{array}{l}-0.479 \\
(0.517)\end{array}$ & $\begin{array}{l}-0.107 \\
(0.413)\end{array}$ & $\begin{array}{l}-0.387 \\
(0.465)\end{array}$ & $\begin{array}{l}-0.356 \\
(0.484)\end{array}$ \\
\hline Change in woman's marital status (lagged) & $\begin{array}{c}1.426 \\
(2.046)\end{array}$ & $\begin{array}{c}2.204 * * \\
(0.905)\end{array}$ & $\begin{array}{l}3.023 * * * \\
(0.985)\end{array}$ & $\begin{array}{l}1.979 * * * \\
(0.748)\end{array}$ & $\begin{array}{c}1.049 \\
(0.649)\end{array}$ & $\begin{array}{c}1.055 \\
(1.021)\end{array}$ \\
\hline $\begin{array}{l}\text { Change in the number of girls aged 0-6 } \\
\text { (lagged) }\end{array}$ & $\begin{array}{c}5.644 * * * \\
(1.726)\end{array}$ & $\begin{array}{l}-0.787 \\
(0.906)\end{array}$ & $\begin{array}{l}-0.679 \\
(0.921)\end{array}$ & $\begin{array}{c}0.117 \\
(0.761)\end{array}$ & $\begin{array}{l}-0.522 \\
(0.634)\end{array}$ & $\begin{array}{c}8.321 * * * \\
(1.062)\end{array}$ \\
\hline $\begin{array}{l}\text { Change in the number of boys aged 0-6 } \\
\text { (lagged) }\end{array}$ & $\begin{array}{c}7.262 * * * \\
(1.522)\end{array}$ & $\begin{array}{c}2.217 * * \\
(0.989)\end{array}$ & $\begin{array}{c}-2.600 * * * \\
(0.778)\end{array}$ & $\begin{array}{l}-0.619 \\
(0.455)\end{array}$ & $\begin{array}{c}-2.116^{* * * *} \\
(0.700)\end{array}$ & $\begin{array}{c}7.671 * * * \\
(1.120)\end{array}$ \\
\hline $\begin{array}{l}\text { Change in the number of girls aged 7-15 } \\
\text { (lagged) }\end{array}$ & $\begin{array}{l}0.836 \\
(1.399)\end{array}$ & $\begin{array}{l}0.512 \\
(0.926)\end{array}$ & $\begin{array}{l}-0.299 \\
(0.897)\end{array}$ & $\begin{array}{l}0.468 \\
(0.614)\end{array}$ & $\begin{array}{l}-0.842 \\
(0.753)\end{array}$ & $\begin{array}{l}1.020 * \\
(0.619)\end{array}$ \\
\hline $\begin{array}{l}\text { Change in the number of boys aged } 7-15 \\
\text { (lagged) }\end{array}$ & $\begin{array}{l}-0.156 \\
(1.160)\end{array}$ & $\begin{array}{l}-0.523 \\
(0.754)\end{array}$ & $\begin{array}{c}0.173 \\
(0.792)\end{array}$ & $\begin{array}{l}-0.671 \\
(0.531)\end{array}$ & $\begin{array}{c}0.824 \\
(0.636)\end{array}$ & $\begin{array}{l}0.832 * \\
(0.505)\end{array}$ \\
\hline $\begin{array}{l}\text { Change in the number of elderly women } \\
\text { aged } 60 \text { and above (lagged) }\end{array}$ & $\begin{array}{c}-3.874 * * \\
(1.737)\end{array}$ & $\begin{array}{c}-3.656 * * * \\
(1.332)\end{array}$ & $\begin{array}{c}0.689 \\
(1.150)\end{array}$ & $\begin{array}{c}1.500 \\
(0.936)\end{array}$ & $\begin{array}{l}-1.031 \\
(0.881)\end{array}$ & $\begin{array}{l}-1.192 \\
(0.878)\end{array}$ \\
\hline $\begin{array}{l}\text { Change in the number of elderly men aged } \\
60 \text { and above (lagged) }\end{array}$ & $\begin{array}{l}-0.043 \\
(1.460)\end{array}$ & $\begin{array}{c}0.201 \\
(0.997)\end{array}$ & $\begin{array}{l}-1.118 \\
(0.784)\end{array}$ & $\begin{array}{c}0.189 \\
(0.504)\end{array}$ & $\begin{array}{l}-1.063 \\
(0.748)\end{array}$ & $\begin{array}{c}0.539 \\
(0.932)\end{array}$ \\
\hline Change in the h'hold size (lagged) & $\begin{array}{l}-0.289 * \\
(0.163)\end{array}$ & $\begin{array}{l}-0.176 \\
(0.117)\end{array}$ & $\begin{array}{l}-0.064 \\
(0.109)\end{array}$ & $\begin{array}{l}-0.068 \\
(0.060)\end{array}$ & $\begin{array}{l}-0.002 \\
(0.093)\end{array}$ & $\begin{array}{l}-0.029 \\
(0.106)\end{array}$ \\
\hline Age $16-20$ in initial year & $\begin{array}{c}1.345 \\
(5.111)\end{array}$ & $\begin{array}{c}1.667 \\
(2.847)\end{array}$ & $\begin{array}{l}4.858 * \\
(2.604)\end{array}$ & $\begin{array}{c}2.501 \\
(1.802)\end{array}$ & $\begin{array}{c}2.840 \\
(2.064)\end{array}$ & $\begin{array}{c}-4.667 * * \\
(2.255)\end{array}$ \\
\hline Age $21-25$ in initial year & $12.365 * * *$ & 3.992 & $5.894 * *$ & $2.834 *$ & $3.723 * *$ & -1.363 \\
\hline
\end{tabular}


Age 26-30 in initial year

Age 31-35 in initial year

Age 36-40 in initial year

Age 41-45 in initial year

Age 46-50 in initial year

Age 51-55 in initial year

Age 56-60 in initial year

Years of schooling in initial year

Years of schooling squared

Years of schooling of head in initial year

Age of head in initial year

Minority household

Household size in initial year

Number of girls 0-6 in initial year

Number of boys 0-6 in initial year

Number of girls 7-15 in initial year

\begin{tabular}{|c|c|c|c|c|c|}
\hline$(4.020)$ & $(2.529)$ & $(2.328)$ & (1.681) & (1.685) & (1.925) \\
\hline $14.048 * * *$ & $6.561 * *$ & $6.402 * * *$ & $4.287 * *$ & 2.099 & -1.284 \\
\hline$(3.500)$ & $(2.620)$ & $(2.280)$ & (1.691) & (1.497) & $(1.690)$ \\
\hline $10.552 * * *$ & $5.282 * *$ & $6.486^{* * *}$ & $4.254 * * *$ & 2.674 & $-2.281 *$ \\
\hline$(3.255)$ & $(2.361)$ & $(2.186)$ & (1.472) & (1.854) & (1.361) \\
\hline $10.328 * * *$ & $5.583 * * *$ & $5.341 * * *$ & $3.582 * * *$ & 2.415 & -1.024 \\
\hline (2.981) & (1.951) & $(2.053)$ & (1.390) & $(1.765)$ & (1.393) \\
\hline $10.370 * * *$ & $6.640 * * *$ & $4.889 * * *$ & $3.325 * * *$ & 1.795 & -1.619 \\
\hline$(2.960)$ & $(2.156)$ & $(1.822)$ & (1.217) & (1.449) & (1.359) \\
\hline $9.805 * * *$ & $7.206 * * *$ & 2.052 & $1.830 *$ & 0.519 & 0.236 \\
\hline$(2.716)$ & (1.925) & (1.555) & $(0.981)$ & (1.332) & $(1.286)$ \\
\hline $5.075^{*}$ & $6.366^{* * *}$ & -1.146 & 0.039 & -0.869 & -0.351 \\
\hline$(2.908)$ & $(2.038)$ & (1.549) & (1.006) & (1.239) & (1.487) \\
\hline $5.529 * *$ & $5.025 * * *$ & -0.321 & -0.144 & 0.342 & 1.168 \\
\hline$(2.815)$ & (1.908) & $(1.735)$ & $(0.924)$ & (1.402) & $(1.412)$ \\
\hline-0.183 & 0.198* & $-0.383 * * *$ & $-0.401 * * *$ & 0.019 & -0.007 \\
\hline$(0.174)$ & (0.119) & $(0.116)$ & (0.097) & $(0.077)$ & $(0.072)$ \\
\hline 0.007 & $-0.018 * * *$ & $0.025 * * *$ & $0.024 * * *$ & 0.000 & 0.000 \\
\hline$(0.007)$ & $(0.004)$ & $(0.005)$ & $(0.005)$ & $(0.003)$ & $(0.003)$ \\
\hline-0.156 & $-0.351 * * *$ & $0.207^{*}$ & $0.135^{* *}$ & 0.061 & -0.018 \\
\hline$(0.166)$ & $(0.106)$ & $(0.116)$ & $(0.066)$ & $(0.101)$ & $(0.070)$ \\
\hline-0.076 & $-0.166 * * *$ & $0.117 * *$ & -0.013 & $0.120 * * *$ & $-0.066^{*}$ \\
\hline$(0.075)$ & $(0.063)$ & $(0.050)$ & $(0.039)$ & $(0.042)$ & $(0.035)$ \\
\hline $4.414 * *$ & $6.012 * * *$ & $-2.407 * *$ & -0.739 & $-1.800^{*}$ & 1.235 \\
\hline$(2.226)$ & $(2.182)$ & (1.109) & $(0.615)$ & $(1.022)$ & $(0.852)$ \\
\hline-0.070 & -0.247 & -0.038 & -0.054 & 0.005 & 0.188 \\
\hline$(0.271)$ & $(0.187)$ & (0.154) & (0.092) & $(0.127)$ & $(0.136)$ \\
\hline $3.545 * *$ & -1.006 & $-1.835 *$ & -0.628 & -1.129 & $7.300 * * *$ \\
\hline (1.733) & (1.197) & (1.086) & $(0.712)$ & $(0.799)$ & $(1.162)$ \\
\hline $\begin{array}{c}5.627 * * * \\
(1.771)\end{array}$ & $\begin{array}{c}0.941 \\
(1.103)\end{array}$ & $\begin{array}{c}-0.850 \\
(1.039)\end{array}$ & $\begin{array}{c}0.498 \\
(0.710)\end{array}$ & $\begin{array}{c}-1.351 * \\
(0.748)\end{array}$ & $\begin{array}{c}5.733 * * * \\
(1.067)\end{array}$ \\
\hline 1.648 & 1.247 & 0.279 & -0.052 & 0.233 & 0.369 \\
\hline
\end{tabular}




\begin{tabular}{|c|c|c|c|c|c|c|}
\hline \multirow{3}{*}{ Number of boys 7-15 in initial year } & $(1.095)$ & $(0.806)$ & $(0.822)$ & $(0.673)$ & $(0.693)$ & $(0.481)$ \\
\hline & 1.343 & $1.954 * *$ & -1.202 & $-1.940 * * *$ & 0.627 & $0.788^{*}$ \\
\hline & $(0.997)$ & $(0.810)$ & $(0.748)$ & $(0.502)$ & $(0.657)$ & $(0.423)$ \\
\hline \multirow[t]{2}{*}{ Number of elderly women in initial year } & 0.283 & 0.901 & 0.288 & 1.832 & -1.137 & -0.982 \\
\hline & $(1.728)$ & $(1.446)$ & $(1.328)$ & $(1.204)$ & $(0.767)$ & $(0.710)$ \\
\hline \multirow[t]{2}{*}{ Number of elderly men in initial year } & -2.421 & 0.391 & -1.660 & -0.583 & -1.042 & -0.382 \\
\hline & $(1.641)$ & $(1.206)$ & $(1.016)$ & $(0.844)$ & $(0.782)$ & $(0.999)$ \\
\hline \multirow[t]{2}{*}{ Never married in initial year } & $-7.810 * *$ & $-3.109 *$ & $-4.111 * *$ & -1.015 & $-3.302 * *$ & $-5.752 * * *$ \\
\hline & $(3.473)$ & $(1.815)$ & $(1.735)$ & $(1.211)$ & $(1.284)$ & $(1.470)$ \\
\hline \multirow[t]{2}{*}{ (log) Income per capita in initial year } & 0.625 & $-1.664 * * *$ & $2.590 * * *$ & $0.967 * * *$ & $1.625 * * *$ & $-0.470 *$ \\
\hline & $(0.605)$ & $(0.497)$ & $(0.373)$ & $(0.273)$ & $(0.256)$ & $(0.264)$ \\
\hline \multirow[t]{2}{*}{ Constant } & $22.973 * * *$ & $30.187 * * *$ & $-25.906 * * *$ & $-6.500^{*}$ & $-17.970 * * *$ & $23.690 * * *$ \\
\hline & $(6.940)$ & $(4.468)$ & $(4.832)$ & $(3.871)$ & $(3.729)$ & $(3.112)$ \\
\hline Number of observations & 3,000 & 3,305 & 3,294 & 3,329 & 3,309 & 3,076 \\
\hline $\mathrm{R}^{2}$ & 0.099 & 0.206 & 0.125 & 0.131 & 0.051 & 0.157 \\
\hline
\end{tabular}

Notes: The sample consists of all women who are present in at least three consecutive survey rounds. Total hours worked equal the sum of hours worked in agriculture (including time spent farming, home gardening, raising livestock/poultry, and fishing.), non-agriculture (including hours in wage labor and family business) and household chores (including buying and preparing food, doing laundry, and child care). Wage labor is defined as work that generates regular wage income in either primary and/or secondary occupations. Family business includes time spent on small handicraft and commercial household businesses. Province/year interactions are also included in the regressions but not reported. Standard errors are clustered at the village level. * denotes significance at $10 \%$ level; $* *$ denotes significance at 5\% level; and $* * *$ denotes significance at $1 \%$ level. 
Table 8: First difference estimates of left behind women's weekly working hours by initial age cohort

\begin{tabular}{|c|c|c|c|c|c|}
\hline & Age16-20 & Age 21-35 & Age 36-50 & Age 51-60 & Age 61-70 \\
\hline Total hours worked & $\begin{array}{l}-9.619 \\
(9.865)\end{array}$ & $\begin{array}{c}0.794 \\
(3.433)\end{array}$ & $\begin{array}{l}-1.206 \\
(1.555)\end{array}$ & $\begin{array}{c}2.793 \\
(2.133)\end{array}$ & $\begin{array}{c}2.470 \\
(5.948)\end{array}$ \\
\hline Obs. No & 122 & 702 & 1,393 & 626 & 157 \\
\hline Hours worked in agriculture & $\begin{array}{c}-2.777 * * \\
(1.377)\end{array}$ & $\begin{array}{c}2.260 \\
(1.629)\end{array}$ & $\begin{array}{l}2.393 * \\
(1.235)\end{array}$ & $\begin{array}{l}3.727 * * * \\
(1.404)\end{array}$ & $\begin{array}{c}0.186 \\
(3.644)\end{array}$ \\
\hline Obs. No & 182 & 816 & 1,463 & 674 & 170 \\
\hline \multirow[t]{2}{*}{$\begin{array}{l}\text { Hours worked in non- } \\
\text { agriculture }\end{array}$} & -4.112 & -1.562 & $-3.404 * * *$ & -1.260 & -0.152 \\
\hline & (5.164) & (2.353) & $(1.031)$ & $(0.943)$ & $(2.304)$ \\
\hline Obs. No & 180 & 806 & 1,456 & 681 & 171 \\
\hline Hours worked in wage labor & $\begin{array}{l}-1.032 \\
(4.668)\end{array}$ & $\begin{array}{l}-0.894 \\
(1.780)\end{array}$ & $\begin{array}{l}-1.298^{*} \\
(0.662)\end{array}$ & $\begin{array}{l}-0.178 \\
(0.124)\end{array}$ & $\begin{array}{c}1.611 \\
(1.598)\end{array}$ \\
\hline Obs. No & 182 & 820 & 1,473 & 683 & 171 \\
\hline \multirow[t]{2}{*}{$\begin{array}{l}\text { Hours worked in family } \\
\text { business }\end{array}$} & $-2.926 * *$ & -1.136 & $-1.849 * *$ & -1.080 & -1.763 \\
\hline & $(1.415)$ & $(1.607)$ & $(0.834)$ & $(0.937)$ & $(1.850)$ \\
\hline Obs. No & 180 & 814 & 1,463 & 681 & 171 \\
\hline \multirow{2}{*}{$\begin{array}{l}\text { Hours worked on household } \\
\text { chores }\end{array}$} & -1.029 & 0.562 & -0.132 & 0.632 & 2.265 \\
\hline & (3.907) & $(2.084)$ & $(0.715)$ & $(1.225)$ & $(4.859)$ \\
\hline Obs. No & 123 & 730 & 1,429 & 636 & 158 \\
\hline
\end{tabular}

Notes: See notes for Table 7. Coefficients on household migration status (lagged) are reported. Other included but unreported variables are the same as are included in Table 7 and province/year interactions. Standard errors are clustered at the village level. * denotes significance at $10 \%$ level; ** denotes significance at $5 \%$ level; and $* * *$ denotes significance at $1 \%$ level. 
Table 9: Impacts of different household members' migration on left behind women's weekly hours worked across activities

\begin{tabular}{|c|c|c|c|c|c|c|}
\hline & $\begin{array}{l}\text { Total hours } \\
\text { worked }\end{array}$ & $\begin{array}{c}\text { Hours in } \\
\text { agriculture }\end{array}$ & $\begin{array}{c}\text { Hours in } \\
\text { non-ag. }\end{array}$ & $\begin{array}{c}\text { Hours in } \\
\text { wage labor }\end{array}$ & $\begin{array}{c}\text { Hours in } \\
\text { family } \\
\text { business }\end{array}$ & $\begin{array}{c}\text { Hours in } \\
\text { household } \\
\text { chores }\end{array}$ \\
\hline \multicolumn{7}{|l|}{ Total } \\
\hline Child migrated & $\begin{array}{c}0.332 \\
(1.252)\end{array}$ & $\begin{array}{c}3.880 * * * \\
(0.969)\end{array}$ & $\begin{array}{c}-2.784 * * * \\
(0.777)\end{array}$ & $\begin{array}{c}-1.245^{* * *} \\
(0.461)\end{array}$ & $\begin{array}{c}-1.553 * * \\
(0.644)\end{array}$ & $\begin{array}{l}-0.346 \\
(0.662)\end{array}$ \\
\hline Husband migrated & $\begin{array}{l}-0.877 \\
(3.740)\end{array}$ & $\begin{array}{c}2.268 \\
(2.222)\end{array}$ & $\begin{array}{l}-2.777 \\
(1.894)\end{array}$ & $\begin{array}{c}-2.800 * * * \\
(0.998)\end{array}$ & $\begin{array}{l}-0.146 \\
(1.686)\end{array}$ & $\begin{array}{l}-0.937 \\
(2.151)\end{array}$ \\
\hline Other migrated & $\begin{array}{l}-0.419 \\
(2.355)\end{array}$ & $\begin{array}{l}-0.393 \\
(1.448)\end{array}$ & $\begin{array}{l}-1.211 \\
(1.408)\end{array}$ & $\begin{array}{c}0.843 \\
(1.183)\end{array}$ & $\begin{array}{c}-1.758^{* *} \\
(0.844)\end{array}$ & $\begin{array}{c}1.539 \\
(1.160)\end{array}$ \\
\hline \multicolumn{7}{|l|}{ Age 16-20 } \\
\hline Other migrated & $\begin{array}{l}-9.619 \\
(9.865)\end{array}$ & $\begin{array}{c}-2.777 * * \\
(1.377)\end{array}$ & $\begin{array}{l}-4.112 \\
(5.164)\end{array}$ & $\begin{array}{l}-1.032 \\
(4.668)\end{array}$ & $\begin{array}{c}-2.926^{* *} \\
(1.415)\end{array}$ & $\begin{array}{l}-1.029 \\
(3.907)\end{array}$ \\
\hline \multicolumn{7}{|l|}{ Age 21-35 } \\
\hline Husband migrated & $\begin{array}{l}-1.521 \\
(4.991)\end{array}$ & $\begin{array}{l}3.673^{*} \\
(2.180)\end{array}$ & $\begin{array}{l}-3.279 \\
(3.251)\end{array}$ & $\begin{array}{c}-3.929 * * \\
(1.695)\end{array}$ & $\begin{array}{c}0.506 \\
(2.797)\end{array}$ & $\begin{array}{l}-2.011 \\
(3.035)\end{array}$ \\
\hline Other migrated & $\begin{array}{c}2.849 \\
(4.063)\end{array}$ & $\begin{array}{c}0.855 \\
(2.402)\end{array}$ & $\begin{array}{c}0.151 \\
(3.078)\end{array}$ & $\begin{array}{c}2.053 \\
(2.668)\end{array}$ & $\begin{array}{l}-2.809^{*} \\
(1.440)\end{array}$ & $\begin{array}{c}2.843 \\
(2.443)\end{array}$ \\
\hline \multicolumn{7}{|l|}{ Age 36-50 } \\
\hline Child migrated & $\begin{array}{l}-1.270 \\
(1.457)\end{array}$ & $\begin{array}{c}2.974 * * \\
(1.243)\end{array}$ & $\begin{array}{c}-3.710^{* * * *} \\
(1.134)\end{array}$ & $\begin{array}{c}-2.020 * * * \\
(0.706)\end{array}$ & $\begin{array}{l}-1.694 * \\
(0.890)\end{array}$ & $\begin{array}{l}-0.440 \\
(0.743)\end{array}$ \\
\hline Husband migrated & $\begin{array}{c}6.894 \\
(4.487)\end{array}$ & $\begin{array}{c}9.453 \\
(6.745)\end{array}$ & $\begin{array}{c}-5.559 * * * \\
(1.848)\end{array}$ & $\begin{array}{c}-4.156^{* * * *} \\
(1.305)\end{array}$ & $\begin{array}{l}-1.214 \\
(2.292)\end{array}$ & $\begin{array}{c}4.038 \\
(4.508)\end{array}$ \\
\hline Other migrated & $\begin{array}{l}-0.394 \\
(3.077)\end{array}$ & $\begin{array}{l}-0.646 \\
(2.100)\end{array}$ & $\begin{array}{l}-0.661 \\
(2.078)\end{array}$ & $\begin{array}{c}1.251 \\
(1.847)\end{array}$ & $\begin{array}{l}-0.994 \\
(1.512)\end{array}$ & $\begin{array}{c}1.016 \\
(1.480)\end{array}$ \\
\hline \multicolumn{7}{|l|}{ Age 51-60 } \\
\hline Child migrated & $\begin{array}{l}3.913^{*} \\
(2.129)\end{array}$ & $\begin{array}{c}4.712 * * * \\
(1.600)\end{array}$ & $\begin{array}{l}-1.446 \\
(0.931)\end{array}$ & $\begin{array}{l}-0.130 \\
(0.123)\end{array}$ & $\begin{array}{l}-1.315 \\
(0.925)\end{array}$ & $\begin{array}{c}0.784 \\
(1.244)\end{array}$ \\
\hline Husband migrated & $\begin{array}{l}-3.084 \\
(8.602)\end{array}$ & $\begin{array}{l}-1.114 \\
(3.345)\end{array}$ & $\begin{array}{c}0.049 \\
(3.170)\end{array}$ & $\begin{array}{l}-0.612 \\
(0.453)\end{array}$ & $\begin{array}{c}0.664 \\
(3.099)\end{array}$ & $\begin{array}{c}0.032 \\
(4.492)\end{array}$ \\
\hline Other migrated & $\begin{array}{c}3.762 \\
(7.313)\end{array}$ & $\begin{array}{c}1.368 \\
(7.015)\end{array}$ & $\begin{array}{c}0.695 \\
(3.251)\end{array}$ & $\begin{array}{c}0.073 \\
(0.288)\end{array}$ & $\begin{array}{c}0.626 \\
(3.247)\end{array}$ & $\begin{array}{c}1.538 \\
(2.931)\end{array}$ \\
\hline \multicolumn{7}{|l|}{ Age 61 and above } \\
\hline Child migrated & $\begin{array}{c}0.917 \\
(5.395)\end{array}$ & $\begin{array}{l}-2.547 \\
(2.877)\end{array}$ & $\begin{array}{c}0.431 \\
(2.113)\end{array}$ & $\begin{array}{l}-1.329 \\
(1.355)\end{array}$ & $\begin{array}{c}1.756 \\
(1.774)\end{array}$ & $\begin{array}{c}6.101 \\
(3.970)\end{array}$ \\
\hline Other migrated & $\begin{array}{l}-7.734 \\
(9.054)\end{array}$ & $\begin{array}{c}1.540 \\
(4.114)\end{array}$ & $\begin{array}{c}3.518 \\
(3.516)\end{array}$ & $\begin{array}{l}-1.385 \\
(1.452)\end{array}$ & $\begin{array}{c}4.696 \\
(3.021)\end{array}$ & $\begin{array}{c}2.913 \\
(4.799)\end{array}$ \\
\hline
\end{tabular}

Notes: See notes for Table 7. Migration variables are valued at a one period lag. Other included but unreported variables are as given in Table 7 along with province/year interactions. Standard errors are clustered at the village level. * denotes significance at $10 \%$ level; $* *$ denotes significance at $5 \%$ level; and $* * *$ denotes significance at $1 \%$ level 
Table 10: Impacts of out versus return migration on left behind women's weekly hours worked across activities

\begin{tabular}{|c|c|c|c|c|c|c|}
\hline & $\begin{array}{c}\text { Total } \\
\text { hours } \\
\text { worked }\end{array}$ & $\begin{array}{c}\text { Hours in } \\
\text { agriculture }\end{array}$ & $\begin{array}{c}\text { Hours in } \\
\text { non-ag. }\end{array}$ & $\begin{array}{c}\text { Hours in } \\
\text { wage labor }\end{array}$ & $\begin{array}{l}\text { Hours in } \\
\text { family } \\
\text { business }\end{array}$ & $\begin{array}{c}\text { Hours in } \\
\text { household } \\
\text { chores }\end{array}$ \\
\hline \multicolumn{7}{|l|}{ Total } \\
\hline Return migration & $\begin{array}{c}0.013 \\
(1.309)\end{array}$ & $\begin{array}{c}1.035 \\
(0.828)\end{array}$ & $\begin{array}{l}-1.361 \\
(0.921)\end{array}$ & $\begin{array}{l}-0.500 \\
(0.522)\end{array}$ & $\begin{array}{l}-0.949 \\
(0.709)\end{array}$ & $\begin{array}{c}0.687 \\
(0.621)\end{array}$ \\
\hline Out migration & $\begin{array}{c}1.313 \\
(1.481)\end{array}$ & $\begin{array}{c}2.682 * * \\
(1.058)\end{array}$ & $\begin{array}{c}-2.350 * * * \\
(0.731)\end{array}$ & $\begin{array}{c}-1.187 * * \\
(0.550)\end{array}$ & $\begin{array}{c}-1.306^{*} \\
(0.675)\end{array}$ & $\begin{array}{c}0.182 \\
(0.833)\end{array}$ \\
\hline \multicolumn{7}{|l|}{ Age 16-20 } \\
\hline Return migration & $\begin{array}{c}0.640 \\
(10.896)\end{array}$ & $\begin{array}{l}-2.532 \\
(3.257)\end{array}$ & $\begin{array}{l}-2.441 \\
(3.755)\end{array}$ & $\begin{array}{l}-1.136 \\
(3.439)\end{array}$ & $\begin{array}{l}-1.157 \\
(1.726)\end{array}$ & $\begin{array}{l}5.982 * * \\
(2.945)\end{array}$ \\
\hline Out migration & $\begin{array}{c}-17.868 * * \\
(8.530)\end{array}$ & $\begin{array}{l}-2.059 \\
(1.732)\end{array}$ & $\begin{array}{c}-8.196^{* * *} \\
(4.168)\end{array}$ & $\begin{array}{l}-5.236 \\
(3.606)\end{array}$ & $\begin{array}{l}-2.698 \\
(2.235)\end{array}$ & $\begin{array}{l}-4.903 \\
(4.108)\end{array}$ \\
\hline \multicolumn{7}{|l|}{ Age 21-35 } \\
\hline Return migration & $\begin{array}{c}0.562 \\
(3.071)\end{array}$ & $\begin{array}{l}3.882 * \\
(2.140)\end{array}$ & $\begin{array}{l}-4.244 * \\
(2.222)\end{array}$ & $\begin{array}{l}-0.109 \\
(2.178)\end{array}$ & $\begin{array}{c}-4.128 * * * \\
(0.908)\end{array}$ & $\begin{array}{l}2.629 * \\
(1.403)\end{array}$ \\
\hline Out migration & $\begin{array}{l}7.084 * \\
(3.934)\end{array}$ & $\begin{array}{l}4.380^{*} \\
(2.288)\end{array}$ & $\begin{array}{c}0.327 \\
(3.390)\end{array}$ & $\begin{array}{l}-0.848 \\
(2.614)\end{array}$ & $\begin{array}{c}0.763 \\
(2.675)\end{array}$ & $\begin{array}{l}1.356 \\
(2.527)\end{array}$ \\
\hline \multicolumn{7}{|l|}{ Age 36-50 } \\
\hline Return migration & $\begin{array}{l}-1.434 \\
(1.500)\end{array}$ & $\begin{array}{c}0.420 \\
(0.868)\end{array}$ & $\begin{array}{l}-1.840 \\
(1.131)\end{array}$ & $\begin{array}{l}-1.087^{*} \\
(0.592)\end{array}$ & $\begin{array}{l}-0.974 \\
(0.933)\end{array}$ & $\begin{array}{c}0.009 \\
(0.700)\end{array}$ \\
\hline Out migration & $\begin{array}{l}-1.009 \\
(2.287)\end{array}$ & $\begin{array}{l}1.246 \\
(1.564)\end{array}$ & $\begin{array}{c}-3.824 * * * \\
(1.302)\end{array}$ & $\begin{array}{c}-2.414 * * * \\
(0.863)\end{array}$ & $\begin{array}{l}-1.544 \\
(1.049)\end{array}$ & $\begin{array}{c}0.617 \\
(1.009)\end{array}$ \\
\hline \multicolumn{7}{|l|}{ Age 51-60 } \\
\hline Return migration & $\begin{array}{c}3.834 \\
(2.825)\end{array}$ & $\begin{array}{c}0.923 \\
(1.800)\end{array}$ & $\begin{array}{l}3.255^{*} \\
(1.874)\end{array}$ & $\begin{array}{c}0.167 \\
(0.245)\end{array}$ & $\begin{array}{l}3.088^{*} \\
(1.854)\end{array}$ & $\begin{array}{c}0.459 \\
(1.847)\end{array}$ \\
\hline Out migration & $\begin{array}{l}1.737 \\
(2.990)\end{array}$ & $\begin{array}{c}3.902 * * \\
(1.931)\end{array}$ & $\begin{array}{l}-1.444 \\
(0.895)\end{array}$ & $\begin{array}{l}-0.191 \\
(0.129)\end{array}$ & $\begin{array}{l}-1.249 \\
(0.896)\end{array}$ & $\begin{array}{l}-0.892 \\
(1.614)\end{array}$ \\
\hline \multicolumn{7}{|l|}{ Age 61 -70 } \\
\hline Return migration & $\begin{array}{l}-2.147 \\
(4.999)\end{array}$ & $\begin{array}{l}-3.238 \\
(2.656)\end{array}$ & $\begin{array}{l}-0.189 \\
(3.183)\end{array}$ & $\begin{array}{l}-0.749 \\
(0.716)\end{array}$ & $\begin{array}{c}0.559 \\
(3.050)\end{array}$ & $\begin{array}{c}0.585 \\
(4.204)\end{array}$ \\
\hline Out migration & $\begin{array}{c}6.074 \\
(9.627)\end{array}$ & $\begin{array}{l}-4.240 \\
(4.828)\end{array}$ & $\begin{array}{c}2.678 \\
(5.071)\end{array}$ & $\begin{array}{c}4.849 \\
(4.397)\end{array}$ & $\begin{array}{l}-2.171 \\
(2.511)\end{array}$ & $\begin{array}{c}6.492 \\
(7.874)\end{array}$ \\
\hline
\end{tabular}

Notes: See notes for Table 7. Migration variables are valued at a one period lag. Out migration is defined as 1 if at least one household member has migrated for work out from time 0 to time 1 , and 0 otherwise.

Return migration is defined as 1 if at least one household member has returned from work-related migration from time $\mathrm{t}-2$ to time $\mathrm{t}-1$. Other included but unreported variables are as given in Table 7 along with province/year interactions. Standard errors are clustered at the village level. * denotes significance at $10 \%$ level; $* *$ denotes significance at $5 \%$ level; and $* * *$ denotes significance at $1 \%$ level. 
Table 11: First difference estimates of impacts on left behind women's other outcome variables

\begin{tabular}{|c|c|c|c|c|c|c|}
\hline & Total & $\begin{array}{c}\text { Age } \\
16-20 \\
\end{array}$ & $\begin{array}{c}\text { Age } \\
21-35 \\
\end{array}$ & $\begin{array}{c}\text { Age } \\
\mathbf{3 6 - 5 0} \\
\end{array}$ & $\begin{array}{c}\text { Age } \\
51-60 \\
\end{array}$ & $\begin{array}{c}\text { Age } \\
61-70 \\
\end{array}$ \\
\hline \multicolumn{7}{|c|}{ Panel A: Having primary responsibility for agricultural activities } \\
\hline In charge of farming & $\begin{array}{c}0.011 \\
(0.022)\end{array}$ & $\begin{array}{c}0.003 \\
(0.013)\end{array}$ & $\begin{array}{l}-0.006 \\
(0.047)\end{array}$ & $\begin{array}{c}0.020 \\
(0.034)\end{array}$ & $\begin{array}{c}0.023 \\
(0.037)\end{array}$ & $\begin{array}{r}0.089 \\
(0.062)\end{array}$ \\
\hline In charge of fishing & $\begin{array}{l}-0.002 \\
(0.004)\end{array}$ & & $\begin{array}{l}-0.012 \\
(0.008)\end{array}$ & $\begin{array}{l}-0.000 \\
(0.006)\end{array}$ & $\begin{array}{c}0.000 \\
(0.010)\end{array}$ & \\
\hline In charge of raising livestock & $\begin{array}{c}0.001 \\
(0.021)\end{array}$ & $\begin{array}{c}0.045 \\
(0.038)\end{array}$ & $\begin{array}{c}0.067 \\
(0.045)\end{array}$ & $\begin{array}{l}-0.037 \\
(0.030)\end{array}$ & $\begin{array}{c}0.021 \\
(0.044)\end{array}$ & $\begin{array}{l}-0.093 \\
(0.124)\end{array}$ \\
\hline \multicolumn{7}{|l|}{ Panel B: Health outcomes } \\
\hline Sick in last 4 weeks & $\begin{array}{l}-0.014 \\
(0.022)\end{array}$ & $\begin{array}{c}0.098 \\
(0.154)\end{array}$ & $\begin{array}{l}-0.003 \\
(0.037)\end{array}$ & $\begin{array}{l}-0.009 \\
(0.027)\end{array}$ & $\begin{array}{c}0.000 \\
(0.042)\end{array}$ & $\begin{array}{l}-0.063 \\
(0.126)\end{array}$ \\
\hline Sick in last 3 months & $\begin{array}{l}-0.008 \\
(0.016)\end{array}$ & $\begin{array}{c}0.424 \\
(0.336)\end{array}$ & $\begin{array}{c}0.044 \\
(0.031)\end{array}$ & $\begin{array}{l}-0.031 \\
(0.020)\end{array}$ & $\begin{array}{c}0.014 \\
(0.040)\end{array}$ & $\begin{array}{r}0.039 \\
(0.110)\end{array}$ \\
\hline Bad health (self reported) & $\begin{array}{l}-0.011 \\
(0.023)\end{array}$ & $\begin{array}{l}-0.025 \\
(0.084)\end{array}$ & $\begin{array}{c}0.080 \\
(0.056)\end{array}$ & $\begin{array}{l}-0.046 \\
(0.029)\end{array}$ & $\begin{array}{c}0.023 \\
(0.046)\end{array}$ & $\begin{array}{l}-0.049 \\
(0.106)\end{array}$ \\
\hline High blood pressure & $\begin{array}{l}-0.027 \\
(0.029)\end{array}$ & & $\begin{array}{l}-0.042 \\
(0.037)\end{array}$ & $\begin{array}{l}-0.005 \\
(0.036)\end{array}$ & $\begin{array}{l}-0.015 \\
(0.076)\end{array}$ & $\begin{array}{l}-1.250 \\
(1.081)\end{array}$ \\
\hline Low blood pressure & $\begin{array}{c}0.007 \\
(0.015)\end{array}$ & & $\begin{array}{c}0.054 \\
(0.092)\end{array}$ & $\begin{array}{c}0.005 \\
(0.017)\end{array}$ & $\begin{array}{c}0.016 \\
(0.031)\end{array}$ & \\
\hline Being overweight & $\begin{array}{c}0.011 \\
(0.016)\end{array}$ & & $\begin{array}{l}-0.012 \\
(0.032)\end{array}$ & $\begin{array}{l}0.039 * \\
(0.021)\end{array}$ & $\begin{array}{c}-0.052 * \\
(0.030)\end{array}$ & $\begin{array}{c}0.073 \\
(0.076)\end{array}$ \\
\hline Being underweight & $\begin{array}{l}-0.000 \\
(0.011)\end{array}$ & & $\begin{array}{c}0.042 \\
(0.031)\end{array}$ & $\begin{array}{c}0.004 \\
(0.012)\end{array}$ & $\begin{array}{l}-0.026 \\
(0.030)\end{array}$ & $\begin{array}{l}-0.062 \\
(0.078)\end{array}$ \\
\hline
\end{tabular}

Notes: Coefficients on household migration status (lagged) are reported. Other variables included in the regressions but not reported are the same as are given in Tables 3 and 7 along with province/year interactions. Standard errors are clustered at the village level. * denotes significance at $10 \%$ level; ** denotes significance at 5\% level; and *** denotes significance at $1 \%$ level. Weight $(\mathrm{kg})$ and height $(\mathrm{cm})$ are measured by health professionals during the survey. BMI is equal to weight/(height/100) ${ }^{2}$. An individual is overweight if his or her BMI is larger than 25; and underweight if it is less than 18.5. Sick in last 4 weeks is equal to 1 if the individual reported being sick or injured during the past four weeks or suffering from a chronic or acute disease, 0 otherwise. Sick in last 3 months is equal to 1 if the respondent reported that he/she had some difficulty carrying out his/her daily activities/work or studies due to illness during the past three months, 0 otherwise. Bad self-reported health is equal to 1 if the reported health status is "fair" or "poor", 0 otherwise. 
Table 12: First difference estimates of left behind men's labor force participation and weekly working hours on various activities

\begin{tabular}{|c|c|c|c|c|c|c|}
\hline Labor force participation & & $\begin{array}{l}\text { Participation } \\
\text { in agriculture }\end{array}$ & $\begin{array}{l}\text { Participation } \\
\text { in non-ag. }\end{array}$ & $\begin{array}{c}\text { Participation } \\
\text { in wage } \\
\text { labor }\end{array}$ & $\begin{array}{c}\text { Participation } \\
\text { in family } \\
\text { business }\end{array}$ & \\
\hline \multicolumn{2}{|l|}{ Migrant household status (lagged) } & 0.006 & 0.006 & 0.001 & 0.006 & \\
\hline Number of observations & & $\begin{array}{c}(0.018) \\
3,062\end{array}$ & $\begin{array}{c}(0.025) \\
3,062\end{array}$ & $\begin{array}{c}(0.016) \\
3,062\end{array}$ & $\begin{array}{c}(0.022) \\
3,062\end{array}$ & \\
\hline $\mathrm{R}^{2}$ & & 0.036 & 0.041 & 0.025 & 0.040 & \\
\hline Weekly working hours & $\begin{array}{c}\text { Total hours } \\
\text { worked }\end{array}$ & $\begin{array}{l}\text { Hours in } \\
\text { agriculture }\end{array}$ & $\begin{array}{l}\text { Hours in non- } \\
\text { agriculture }\end{array}$ & $\begin{array}{c}\text { Hours in } \\
\text { wage labor }\end{array}$ & $\begin{array}{c}\text { Hours in } \\
\text { family } \\
\text { business }\end{array}$ & $\begin{array}{c}\text { Hours in } \\
\text { household } \\
\text { chores }\end{array}$ \\
\hline Migrant household status (lagged) & $\begin{array}{l}-0.346 \\
(1.103)\end{array}$ & $\begin{array}{l}-0.628 \\
(0.538)\end{array}$ & $\begin{array}{c}0.099 \\
(0.908)\end{array}$ & $\begin{array}{l}-0.428 \\
(0.635)\end{array}$ & $\begin{array}{l}-0.063 \\
(0.702)\end{array}$ & $\begin{array}{c}0.004 \\
(0.009)\end{array}$ \\
\hline Number of observations & 2,459 & 3,018 & 2,929 & 3,013 & 3,015 & 2,625 \\
\hline $\mathrm{R}^{2}$ & 0.051 & 0.060 & 0.019 & 0.022 & 0.022 & 0.044 \\
\hline
\end{tabular}

Notes: The sample consists of all men who are present in at least three consecutive survey rounds. Participation in a labor force activity is a binary variable equal to 1 if the respondent reported being engaged or having positive working hours in the activity and 0 otherwise. Total hours worked equal the sum of hours

worked in agriculture (including time spent farming, home gardening, raising livestock/poultry, and fishing.), non-agriculture (including hours in wage labor and family business) and household chores (including buying and preparing food, doing laundry, and child care). Wage labor is defined as work that generates regular wage income in either primary and/or secondary occupations. Family business includes time spent on small handicraft and commercial household businesses. The regressions control for a large set of household and individual characteristics and province/year interactions similarly to regressions reported in Tables 3 and 7 . Standard errors are clustered at the village level. * denotes significance at $10 \%$ level; ** denotes significance at 5\% level; and $* * *$ denotes significance at $1 \%$ level. 


\begin{tabular}{|c|c|c|c|c|c|c|}
\hline \multirow[b]{2}{*}{ aged $16-20$} & \multicolumn{2}{|c|}{ Total } & \multicolumn{2}{|c|}{ Migrant households } & \multicolumn{2}{|c|}{$\begin{array}{c}\text { Non-migrant } \\
\text { households }\end{array}$} \\
\hline & 0.075 & $(0.264)$ & 0.062 & $(0.241)$ & 0.08 & $(0.272)$ \\
\hline aged $21-25$ & 0.072 & $(0.258)$ & 0.034 & $(0.181)$ & 0.083 & $(0.276)$ \\
\hline aged $26-30$ & 0.103 & $(0.304)$ & 0.04 & $(0.196)$ & 0.123 & $(0.328)$ \\
\hline aged $31-35$ & 0.124 & $(0.330)$ & 0.104 & $(0.306)$ & 0.132 & $(0.339)$ \\
\hline aged $36-40$ & 0.113 & $(0.316)$ & 0.128 & $(0.335)$ & 0.108 & $(0.310)$ \\
\hline aged $41-45$ & 0.132 & $(0.338)$ & 0.198 & $(0.399)$ & 0.108 & $(0.310)$ \\
\hline aged $46-50$ & 0.138 & $(0.345)$ & 0.196 & $(0.397)$ & 0.118 & $(0.322)$ \\
\hline aged $51-55$ & 0.113 & $(0.316)$ & 0.13 & $(0.337)$ & 0.107 & $(0.310)$ \\
\hline aged $56-60$ & 0.084 & $(0.278)$ & 0.07 & $(0.256)$ & 0.091 & $(0.288)$ \\
\hline aged 61-64 & 0.046 & $(0.209)$ & 0.037 & $(0.190)$ & 0.05 & $(0.217)$ \\
\hline years of schooling & 6.747 & $(3.556)$ & 6.729 & $(3.331)$ & 6.736 & $(3.675)$ \\
\hline years of schooling of head & 6.821 & $(3.486)$ & 6.771 & $(3.184)$ & 6.817 & $(3.613)$ \\
\hline age of head & 47.302 & $(10.659)$ & 46.923 & $(8.865)$ & 47.45 & $(11.291)$ \\
\hline ethnic minority household head & 0.136 & $(0.343)$ & 0.162 & $(0.369)$ & 0.127 & $(0.333)$ \\
\hline household size & 4.292 & $(2.145)$ & 4.691 & $(2.293)$ & 4.117 & $(2.062)$ \\
\hline number of girls younger than 6 & 0.102 & $(0.318)$ & 0.071 & $(0.283)$ & 0.114 & $(0.329)$ \\
\hline number of boys younger than 6 & 0.133 & $(0.371)$ & 0.094 & $(0.309)$ & 0.146 & $(0.390)$ \\
\hline number of girls aged 7-15 & 0.308 & $(0.571)$ & 0.47 & $(0.677)$ & 0.248 & $(0.514)$ \\
\hline number of boys aged 7-15 & 0.354 & $(0.579)$ & 0.52 & $(0.664)$ & 0.292 & $(0.530)$ \\
\hline number of working age men (16-60) & 1.556 & $(0.784)$ & 1.682 & $(0.841)$ & 1.515 & $(0.757)$ \\
\hline number of working age women (16-60) & 1.509 & $(0.865)$ & 1.528 & $(0.798)$ & 1.518 & $(0.885)$ \\
\hline number of elderly women (60 or older) & 0.136 & $(0.350)$ & 0.133 & $(0.342)$ & 0.139 & $(0.355)$ \\
\hline number of elderly men ( 60 or older) & 0.117 & $(0.324)$ & 0.087 & $(0.282)$ & 0.131 & $(0.340)$ \\
\hline married & 0.787 & $(0.410)$ & 0.826 & $(0.379)$ & 0.775 & $(0.418)$ \\
\hline single & 0.17 & $(0.376)$ & 0.128 & $(0.334)$ & 0.183 & $(0.387)$ \\
\hline household real income per capita $(\log )$ & 7.937 & $(1.084)$ & 7.777 & $(1.114)$ & 8.012 & $(1.062)$ \\
\hline household member has bad health & 0.088 & $(0.283)$ & 0.111 & $(0.314)$ & 0.08 & $(0.271)$ \\
\hline Liaoning & 0.052 & $(0.222)$ & 0.041 & $(0.198)$ & 0.057 & $(0.231)$ \\
\hline Heilongjiang & 0.117 & $(0.322)$ & 0.031 & $(0.174)$ & 0.153 & $(0.360)$ \\
\hline Jiangsu & 0.092 & $(0.289)$ & 0.098 & $(0.298)$ & 0.089 & $(0.285)$ \\
\hline Shandong & 0.138 & $(0.345)$ & 0.087 & $(0.282)$ & 0.158 & $(0.365)$ \\
\hline Henan & 0.113 & $(0.316)$ & 0.127 & $(0.333)$ & 0.108 & $(0.310)$ \\
\hline Hubei & 0.114 & $(0.318)$ & 0.172 & $(0.377)$ & 0.09 & $(0.286)$ \\
\hline Hunan & 0.107 & $(0.310)$ & 0.116 & $(0.321)$ & 0.105 & $(0.306)$ \\
\hline Guangxi & 0.143 & $(0.350)$ & 0.189 & $(0.392)$ & 0.122 & $(0.328)$ \\
\hline Guizhou & 0.124 & $(0.330)$ & 0.139 & $(0.346)$ & 0.118 & $(0.323)$ \\
\hline obs. & \multicolumn{2}{|c|}{3401} & \multicolumn{2}{|c|}{1252} & \multicolumn{2}{|c|}{2149} \\
\hline
\end{tabular}




\section{Appendix Table 2: Determinants of migration 2000-2006: Marginal effects estimated from a Probit model}

\begin{tabular}{|c|c|c|c|c|}
\hline & \multicolumn{2}{|c|}{ Women } & \multicolumn{2}{|c|}{ Men } \\
\hline & coef & se & coef & se \\
\hline Aged 7-16 in 1997 & $0.605 * * *$ & 0.098 & $0.490 * * *$ & 0.098 \\
\hline Aged 17-23 in 1997 & $0.540 * * *$ & 0.124 & $0.417 * * *$ & 0.124 \\
\hline Aged 24-30 in 1997 & $0.460 * * *$ & 0.117 & $0.342 * * *$ & 0.117 \\
\hline Aged 31-35 in 1997 & $0.321 * * *$ & 0.107 & $0.208 * * *$ & 0.107 \\
\hline Aged 36-52 in 1997 & $0.132 * *$ & 0.064 & $0.087 * *$ & 0.064 \\
\hline Years of schooling in 1997 & $0.020 * * *$ & 0.007 & $0.008^{* *}$ & 0.007 \\
\hline Years of schooling in 1997 squared & -0.001 & 0.000 & -0.000 & 0.000 \\
\hline Age interaction with years of schooling & $-0.000 * *$ & 0.000 & $-0.000 * *$ & 0.000 \\
\hline Was married & -0.041 & 0.027 & 0.005 & 0.027 \\
\hline Had child(ren) in 1997 & -0.013 & 0.017 & 0.015 & 0.017 \\
\hline Head's years of schooling in 1997 & $-0.006 * * *$ & 0.001 & $-0.006 * * *$ & 0.001 \\
\hline Number of girls less than 6 in 1997 & -0.011 & 0.013 & -0.006 & 0.013 \\
\hline Number of boys less than 6 in 1997 & 0.003 & 0.010 & -0.004 & 0.010 \\
\hline Number of girls aged 7-15 in 1997 & 0.002 & 0.006 & $0.013 *$ & 0.006 \\
\hline Number of boys aged 7-15 in 1997 & $0.018 * *$ & 0.008 & $0.024 * * *$ & 0.008 \\
\hline Number of working age women (16-60) in 1997 & -0.003 & 0.008 & 0.002 & 0.008 \\
\hline Number of working age men (16-60) in 1997 & $0.028 * * *$ & 0.007 & $0.026 * * *$ & 0.007 \\
\hline Number of women $60+$ in 1997 & 0.001 & 0.012 & -0.017 & 0.012 \\
\hline Number of men $60+$ in 1997 & -0.011 & 0.015 & -0.083 & 0.015 \\
\hline Being in a migrant household in 1997 & 0.013 & 0.019 & 0.001 & 0.019 \\
\hline Father/father-in-law alive in 1997 & 0.016 & 0.013 & 0.091 & 0.013 \\
\hline Mother/mother-in-law alive in 1997 & -0.028 & 0.020 & 0.016 & 0.020 \\
\hline Household assets per capita in 1997 (log) & $0.046^{*}$ & 0.026 & $0.016 * *$ & 0.026 \\
\hline Assets squared & $-0.005 * *$ & 0.002 & $-0.002 * * *$ & 0.002 \\
\hline$\%$ of people in the village migrated in 1997 & $0.003 *$ & 0.001 & 0.888 & 0.001 \\
\hline Migration *education & 0.000 & 0.000 & 0.043 & 0.000 \\
\hline Village had a primary school in 1997 & $0.024 * * *$ & 0.009 & $0.020 *$ & 0.009 \\
\hline Village had a junior middle school in 1997 & 0.015 & 0.016 & 0.014 & 0.016 \\
\hline Village had a senior middle school in 1997 & $-0.033 * *$ & 0.013 & $-0.028 *$ & 0.013 \\
\hline \% villagers working in large enterprises in 1997 & $-0.001 * *$ & 0.000 & $-0.001 *$ & 0.000 \\
\hline
\end{tabular}




\begin{tabular}{lcccc} 
\% villagers working in small enterprises in 1997 & $-0.001 * *$ & 0.000 & -0.000 & 0.000 \\
Distance to the nearest bus stop in 1997 & 0.003 & 0.002 & 0.003 & 0.002 \\
Distance $(\mathrm{km})$ to nearest public bath & $0.001 * *$ & 0.000 & 0.000 & 0.000 \\
Telephone service available in the village in 1997 & 0.018 & 0.012 & 0.003 & 0.012 \\
Guizhou & -0.000 & 0.018 & -0.020 & 0.018 \\
Heilongjiang & $-0.068 * * *$ & 0.010 & $-0.079 * * *$ & 0.010 \\
Jiangsu & 0.026 & 0.024 & 0.013 & 0.024 \\
Shandong & -0.002 & 0.018 & $-0.027 *$ & 0.018 \\
Hubei & $0.042 *$ & 0.025 & 0.033 & 0.025 \\
Hunan & -0.016 & 0.016 & $-0.031^{* *}$ & 0.016 \\
Guangxi & -0.010 & 0.021 & -0.006 & 0.021 \\
\hline Number of observations & 3,301 & & 3,419 \\
Pseudo $\mathrm{R}^{2}$ & 0.369 & & 0.360 \\
\hline
\end{tabular}

Note: Estimated probit coefficients are transformed into marginal impacts, evaluated at the mean of the dependent variable. Robust t statistics (corrected for serial correlation within village and arbitrary heteroskedasticity) in parentheses. * denotes significance at $10 \%$ level; ** denotes significance at $5 \%$ level; and *** denotes significance at $1 \%$ level. 
Appendix Table 3: Sample means of labor force participation and working hours

\begin{tabular}{|c|c|c|c|c|}
\hline & 1997 & 2000 & 2004 & 2006 \\
\hline \multicolumn{5}{|c|}{ Non-migrant Women } \\
\hline \multicolumn{5}{|l|}{ Labor Force Participation } \\
\hline Participation in agriculture & .74 & .64 & .57 & .58 \\
\hline Participation in non-agriculture & .76 & .67 & .48 & .46 \\
\hline Participation in family business & .12 & .12 & .09 & .1 \\
\hline Participation in wage labor & .66 & .56 & .4 & .37 \\
\hline \multicolumn{5}{|l|}{ Weekly Working Hours } \\
\hline Total working hours & 44.78 & 37.45 & 37.13 & 34.75 \\
\hline Working hours in agriculture & 17.57 & 12.84 & 9.93 & 8.79 \\
\hline Working hours in non-agriculture & 7.96 & 7.44 & 6.68 & 7.01 \\
\hline Working hours in family business & 3.34 & 3.30 & 3.35 & 3.64 \\
\hline Working hours in wage labor & 4.70 & 4.22 & 3.38 & 3.51 \\
\hline Working hours in household chores & 18.62 & 16.66 & 17.9 & 16.99 \\
\hline \multicolumn{5}{|c|}{ Non-migrant Men } \\
\hline \multicolumn{5}{|l|}{ Labor Force Participation } \\
\hline Participation in agriculture & .81 & .73 & .73 & .73 \\
\hline Participation in non-agriculture & .84 & .76 & .62 & .6 \\
\hline Participation in family business & .24 & .21 & .19 & .21 \\
\hline Participation in wage labor & .65 & .58 & .47 & .44 \\
\hline \multicolumn{5}{|l|}{ Weekly Working Hours } \\
\hline Total working hours & 32.62 & 27.05 & 28.53 & 26.87 \\
\hline Working hours in agriculture & 14.37 & 9.84 & 9.40 & 7.57 \\
\hline Working hours in non-agriculture & 14.47 & 12.43 & 12.09 & 12.51 \\
\hline Working hours in family business & 4.95 & 4.57 & 5.37 & 5.22 \\
\hline Working hours in wage labor & 9.73 & 8.27 & 7.18 & 7.88 \\
\hline Working hours in household chores & 3.21 & 4.13 & 4.37 & 4.61 \\
\hline
\end{tabular}

Notes: Means are reported for the non-migrant women and men who are in the survey for at least three consecutive rounds. For women: the number of observations for 1997, 2000, 2004 and 2006 is 2114, 2689, 2689 and 2354 respectively and the number with non-missing values is 1836, 2420, 2136 and 1971 respectively. For men: the number of observations for 1997, 2000, 2004 and 2006 is 2023, 2479, 2479 and 2074 respectively and the number with non-missing working hours is 1844, 2243, 2104 and 1801 respectively 